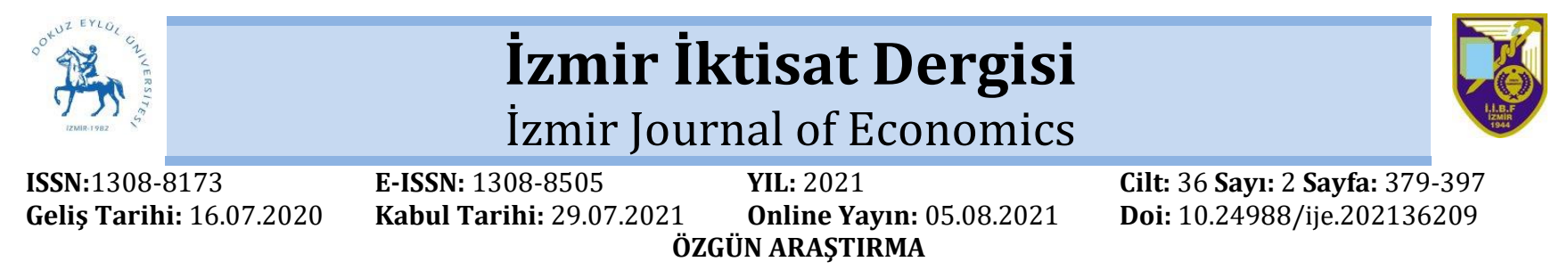

\title{
Kirlilik Emisyonlarının Azaltılmasında Çevre Vergilerinin Rolü: AB Ülkeleri Örneği
}

\author{
Melike ATAY POLAT ${ }^{1}$, Suzan ERGÜN ${ }^{2}$ \\ Özet
}

Ekonomik literatürde çevre vergileri, kirlilik ve iklim değişikliği gibi çevre sorunlarının azaltılmasında temel araçlardan biri olarak önerilmiştir. Bu tür vergiler ekonomik birimlerin dışsal maliyetlerini içselleş̧irdiği için teşvik temelli mekanizmalar olarak sınıflandırılmaktadır. Bu çalışma 21 AB ülkesi için 1995-2017 yılları arasında çevre vergileri ve hava kirliliği ile ilgili seragazı, karbondioksit, sülfür oksit, nitrojen oksit gibi çeșitli kirlilik emisyonları arasındaki ilişkiyi incelemeyi amaçlamıştır. Panel AMG tahmincisi sonuçları pek çok AB ülkesinde çevre vergilerinin seragazı, karbondioksit, sülfür oksit, nitrojen oksit gibi çevresel kirlilik emisyonlarını azalttığını ortaya koymuștur. Ayrıca, çevre vergisinden seragazı emisyonuna doğru tek yönlü, sülfüroksit emisyonundan çevre vergisine doğru tek yönlü, çevre vergisi ile $\mathrm{CO}_{2}$ emisyonu ve nitrojenoksit emisyonları arasında ise iki yönlü nedensellik ilişskisi tespit edilmiștir.

\section{Anahtar kelimeler: Çevre Vergisi, Çevresel Kirlilik, Panel Veri Analizi \\ Jel Kodu: H23, Q53, C33}

\section{The Role of Environmental Taxes in Reducing Pollution Emissions: The Case of EU Countries}

\begin{abstract}
In the economic literature environmental taxes have been proposed as one of the main tools for reducing environmental problems such as pollution and climate change. Such type taxes are classified as incentive-based mechanisms as they internalize the external costs of economic units. This study aimed to examine the relationship between environmental taxes and various pollution emissions such as greenhouse gas, carbon dioxide, sulfur oxides, nitrogen oxides related to air pollution and for 21 EU countries between 1995-2017. Panel AMG estimator results revealed that environmental taxes reduce environmental pollution emissions such as greenhouse gases, carbon dioxide, sulfur oxides, nitrogen oxides in many EU countries. In addition, it is found that a one-way causality from environmental tax to greenhouse gas emission and from sulfuroxide emission to environmental tax, bilateral causality relationship between environmental tax and $\mathrm{CO}_{2}$ emission and nitrogen oxide emissions.
\end{abstract}

Keywords: Environmental Tax, Environmnetal Pollution, Panel Data Analysis

Jel Codes: H23, Q53, C33

\section{GİRIŞ}

Ekonomik büyümenin ve kitlesel tüketimin neden olduğu çevresel sorunlar hükümetler üzerinde çevresel zararı azaltmanın yollarını bulma baskısını artırmaktadır. $\mathrm{Bu}$ amaçla hükümetler çeşitli düzenlemeler, bilgi programları, yenilik politikaları, çevresel sübvansiyonlar ve çevre vergileri dâhil olmak üzere bir dizi araca sahiptir. Özellikle çevre vergileri bu araç setinin önemli bir parçasıdır. Çevre vergilerinin çevre politikasında önemli bir rol oynamasının temel nedeni, çevreye verilen hasarı azaltmaya, dışsallıkları içselleştirmeye ve yaşam kalitesini arttırmaya yardımcı olmasıdır. $\mathrm{Bu}$ açıdan çevre vergileri birçok ülkede katı atık, su ve hava kirliliğini engellemede kullanılmaktadır. $\mathrm{Bu}$ olumlu etkilerle birlikte merkezi ve yerel yönetimler için gelir elde edilmesine izin vermesi çevre

ATIF ÖNERİsí (APA): Atay Polat, M., Ergün, S. (2021). Kirlilik Emisyonlarının Azaltılmasında Çevre Vergilerinin Rolü: AB Ülkeleri Örneği. İzmir İktisat Dergisi. 36(2). 379-397. Doi: 10.24988/ije.202136209

1 Doç. Dr., Mardin Artuklu Üniversitesi, İktisadi ve İdari Bilimler Fakültesi, MARDİN, EMAIL: matay@artuklu.edu.tr ORCID:0000-0001-9507-5942

2 Prof. Dr., İnönü Üniversitesi, İktisadi ve İdari Bilimler Fakültesi, MALATYA, EMAIL: suzan.ergun@inonu.edu.tr ORCID:0000-0002-8447-972X 
vergilerinin bir diğer olumlu yanıdır. Yani çevre vergileri, ç̧evresel etkinlik, ekonomik verimlilik, kamu gelirini artırma yeteneği ve şeffaflık gibi birçok önemli avantaja sahiptir. Ancak çevre vergilerinin söz konusu bu olumlu etkilerinin ortaya çıkması hanehalklarının ve firmaların davranışları, teknoloji geliștirme gibi pek çok faktöre bağlıdır. Bununla birlikte çevresel düzenlemeler sosyoekonomik etkilere de sahiptir. Şöyle ki, çevre politikalarında ekonomik araçların kullanılması ekonomik büyümeyi ve refahı azaltabilir, rekabeti etkileyebilir ve bazı sosyal gruplar için daha maliyetli sonuçlar ortaya koyabilir. Bununla birlikte uygulanan çevre politikalarının çifte kazanç sağlayacağına dair kanıtlar da mevcuttur. Örneğin çevre politikasında ekonomik araçların kullanılması teknolojinin yayılmasını teşvik edebilir, istihdamı artırabilir, daha düşük bir emisyon seviyesini, en yüksek üretim hacmini ve en düşük piyasa fiyatını temin etmenin yanı sıra, gelir artışı sağlayabilir. Ayrıca, çevre reformunun bir sonucu olarak çevresel ve ekonomik verimlilikteki iyileşmeyle birlikte yoksulluk da azaltılırsa üçlü bir kazanç elde edilmiş olur. $\mathrm{Bu}$ nedenle çevre vergisi uygulamasında bilime dayalı ve akılcı çevre vergisi politikası çok önemlidir (OECD, 2011: 1; Māris ve Jānis: 2017: 136; Alvarez, 2019: 382).
Hükümetler, çevre politikalarını uygulamak ve uluslararası çevre anlaşmalarına taahhütlerini yerine getirmek için bir dizi çevre politikası aracı kullanabilir. Çevre politikası araçları kabaca üç geniş kategoriye ayrlabilir: i) Düzenleyici/idari (Komuta-kontrol) araçlar kural koyucu olan ve özel sektöre hedeflerine ulaşmada nispeten az esneklik sağlayan düzenlemeler, direktifler, yasaklar, izinler gibi araçlardır. ii) Piyasa temelli araçlar vergiler, harçlar, ticarete konu olan izin programları, mevduat geri ödeme sistemleri, sübvansiyonlar gibi araçlardır. $\mathrm{Bu}$ araçlar, üreticilere ve tüketicilere doğal kaynakların daha verimli kullanımına yönelik davranışlarını değiștirmeleri için teşvikler sağlamak için kullanılabilir ve bir ekonomi veya bölge genelinde, ekonomik sektörler arasında veya çevresel ortam (örneğin su) yoluyla sistematik bir şekilde uygulanabilir. iii) Gönüllü anlaşmalar ve bilgi stratejileri/ahlaki ikna, hükümet ve özel firmalar arasındaki ikili anlaşmalar ve firmalar tarafından yapılan gönüllü taahhütler gibi, hükümet gerekliliğinden bağımsız gönüllü çevresel önlemlerdir. Davranışta gönüllü değişiklikler, eğitim, bilgi aktarımı, ikna gibi yollarla da gerçekleștirilebilir (INTOSAI Working Group on Environmental Auditing, 2016: 17-18).

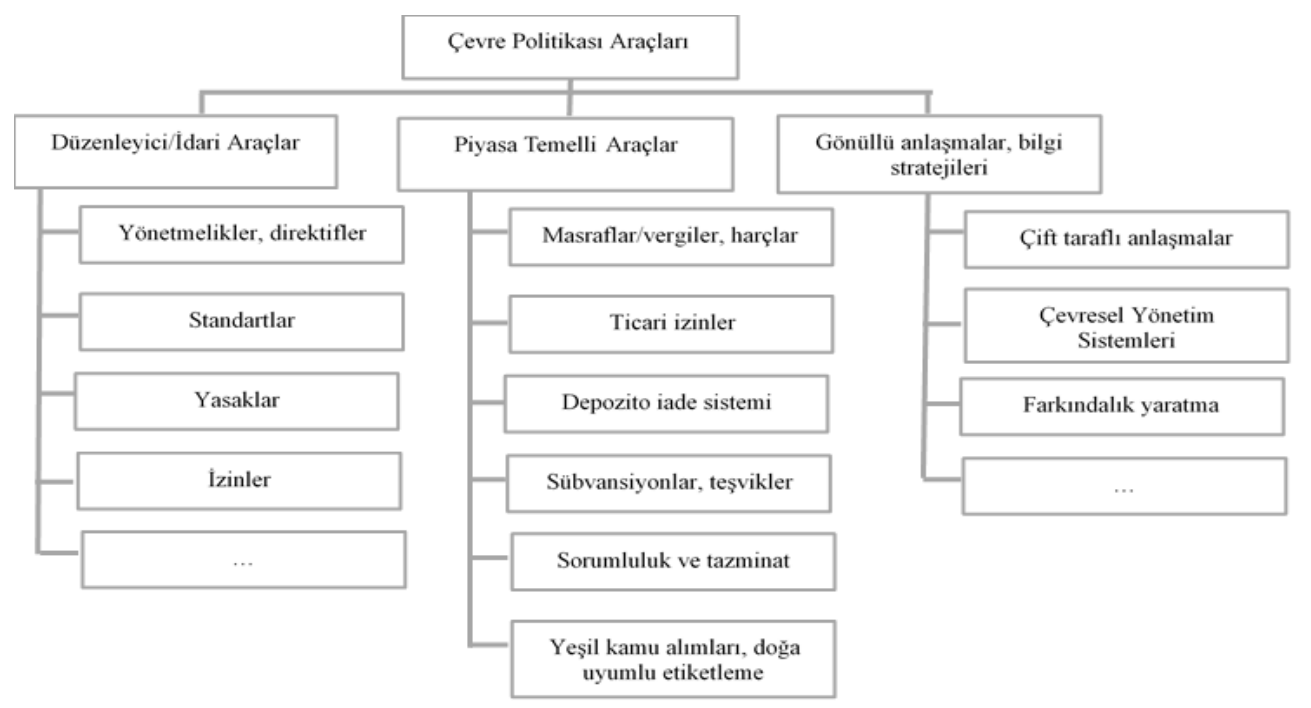

Şekil 1: Çevre Politikası Araçlarının Sınıflandırılması (Kaynak: INTOSAI Working Group on Environmental Auditing, 2016: 18) 
Piyasa temelli araçların bir alt kümesi olan çevre vergileri, "vergi tabanı çevre üzerinde ispatlanmış belirli bir olumsuz etkisi olan fiziksel bir birim (veya bunun bir vekili) olan" vergilerdir. Çevre vergileri tanımının vergiyi, çevresel zararın boyutuna veya dış maliyete açık bir șekilde bağlamadığını, bunun yerine yalnızca vergi tabanını ifade ettiğini belirtmek gerekir (OECD, 2017: 6).

Ekonomik bir bakış açısından çevre vergisi bir mal veya hizmetin üretimi veya tüketimi sırasında üretici veya tüketici dışında üçüncü bir tarafa zarar verdiğinde ortaya çıkan "negatif dışsallık" sorununu çözmeye çalışır. Negatif dıșsallık, doğrudan ilgili üreticiler veya tüketiciler tarafından ödenen fiyatların dışında olan ve karar verme süreçlerinde dikkate alınmayan sağlık ve temizlik maliyetleri gibi "dış maliyetleri" ifade eder. Piyasadaki yanlıș fiyat sinyallerini ve aşırı kirletici emisyonlarını düzeltmek için çevresel zararın maliyetlerini mal ve hizmet fiyatlarına dahil etmek için çevre vergileri kullanılır. Çevre vergilendirmesinin ekonomik mantığı XX. yüzyılın ilk yarısında İngiliz ekonomist Arthur Pigou tarafından geliştirilmiştir. Pigou (1920), emisyonlar üzerindeki optimal bir verginin marjinal çevresel maliyete eşit ayarlanması gerektiğini göstermiştir. Böyle bir "Pigovian vergi" kirleticilerin, kirletici malları üretmelerinin veya tüketmelerinin marjinal sosyal maliyetini tamamen ödemelerini sağlayabilir. Bu nedenle çevre vergileri "düzeltici" vergiler olarak nitelendirilmektedir. Bu vergiler diğer daha az kirletici mal ve hizmetlere göre bu mal ve hizmetlerin fiyatlarını yükselterek daha az üretilmelerini veya daha az tüketilmelerini teşvik ettikleri için ekonomik birimlerin davranıșlarını daha çevre dostu hale getirirler. Ekonomistler için çevre vergilerinin bu düzeltici rolü çok önemlidir. Vergi gelirlerinin harcanma şekli ikincil öneme sahiptir (Baiardi ve Menegatti 2010: 1-2; Cadoret ve diğerleri, 2020).

Rosiek (2015) ve OECD (2011) çevre vergisinde bulunması gereken işlevleri şu şekilde özetlemektedir: i) Çevre vergisi matrahları, birkaç istisna dışında, kirleticiye/kirletici davranışa yönelik olmalıdır. ii) Kapsamları, çevresel zararın kapsamı kadar geniş olmalıdır. iii) Vergi oranı çevresel zararla orantılı, güvenilir, açık, öngörülebilir, koordineli ve geçişli olmalıdır. iv) Ayrıca çevre vergisi gelirleri mali konsolidasyona yardımcı olabilir veya diğer vergileri azaltmaya yardımcı olabilir. v) Dağılımsal etkileri diğer politika araçlarıyla ele alınabilir ve genellikle ele alınmalıdır. vi) Rekabetçilik endişelerinin dikkatle değerlendirilmesi gerekir. vii) Açık iletişim, halkın çevre vergilendirmesini kabulü için kritik öneme sahiptir. viii) Çevresel vergilerin belirli konuları ele almak için diğer politika araçlarıyla birleştirilmesi gerekebilir.

Çevre vergilerinin söz konusu bu özelliklerine rağmen ortaya çıkan bazı olumsuz yönleri de mevcuttur. Başlıca olumsuzlukları (Zoltán, 2013: 518-519): i) Çevre vergileri belirli kirlilik seviyesini garanti etmezler. ii) Çevre vergilerinin etkin bir şekilde uygulanması kirliliği azaltacak uygun teknolojinin seçilmesi ve maliyet analizi açısından büyük ișletmeler için önemli bir sorun anlamına gelmektedir. iii) Deneyim eksikliği, çevre vergilerinin uygulanması alanında önemli bir engel anlamına gelmektedir. iv) Çevre vergilerinin uygulanması için düzenleyici, idari ve icra mekanizmaları gerekmektedir. Bu da idari ve icra maliyetleri anlamına gelir. v) Genellikle farklı emisyon kaynakları için birleşik emisyon vergisi uygulanır. Ancak bu uygulama kaynak bazlı vergi değerlendirmesi kadar verimli değildir. vi) Çevre vergilerinin çevresel zarar verici etkileri olabilir. Atık malzemeler üzerindeki vergiler atığı azaltmaya neden olabilir, ancak yasadıșı yerleștirme ve atık yakmayı da tetikleyebilir. vii) Çevre vergileri siyasi etkiye sahiptir. Şöyle ki kirleticiler birçok durumda vergileri reddeder ve başka araçların uygulanmasını tercih ederler, böylece kirleticiler siyasi pozisyonları etkileyebilir. viii) Çevre vergileri ulaştırmaya, yakıtların karbon içeriğine veya enerjiye uygulanır. Düşük gelirli hane halkı harcamalarının çoğunluğu enerji ve ulaşım maliyetlerinden oluştuğundan çevre vergilerinin artmasıyla birlikte fiyatlar artacak 


\section{ATAY POLAT - S. ERGÜN}

ve hanehalkı gelirleri azalacaktır. Çevre vergisi oranlarındaki değişim daha yüksek gelire sahip hane halklarını daha az etkilemektedir. ix) Kirleticilerin tutumu ve algısı çevre vergilerinin etkisini güçlendirebilir veya zayıflatabilir. $\mathrm{x}$ ) Çevre vergilerinden sosyal açıdan optimal bir sonuç elde etmek kolay değildir ve en verimli vergi oranını belirlemek için açık bir formül mevcut değildir. Yine de çevre vergileri, ekonomide sürdürülebilirliğin sağlanması için temel araçtır. Çevreye zararlı malların fiyatlarını diğer mallara göre artırarak tüketicileri tüketim kalıplarını daha sürdürülebilir bir yöne kaydırmaya teşvik ederler. Çevre vergileri aynı zamanda üretim girdilerinin fiyatlarını artırabilir ve böylece üreticileri daha çevre dostu teknolojiler kullanmaya teşvik edebilir. Çevre vergilerinin en yaygın biçimleri ve mali açıdan en önemlileri, enerji ve ulaşım üzerinden alınan vergilerdir. $\mathrm{Bu}$ vergiler, modern yaşamın bir gereği olarak kabul edilebilecek ısıtma, elektrik ve ulaşım maliyetlerini etkiler. Genellikle, bu tür mallara vergi koymanın, düşük gelirli hane halklarına daha ağır bir yük getireceğine inanılmaktadır. Çünkü düşük gelirli grupların gelirlerine oranlandığında bu tür mal ve hizmetlere daha fazla harcama yaptığ bilinen bir gerçektir (Kosonen, 2012: 1; Alvarez, 2019: 383).

Özetle, çevre vergileri için temel teşvik, devlet müdahalesi olmadan firmaların ve hane halklarının çevresel hasarı hesaba katmalarını sağlayacak herhangi bir piyasa mekanizmasının olmayıșıdır. Kirliliğe yol açan üretim ve tüketim faaliyetlerinin seviyesi, teknoloji seçimi, kirliliği azaltma önlemlerinin kullanımı ve atık ürünlerin bertarafına ilişkin kararlar tamamen 'özel' maliyet ve faydalar temelinde alınacaktır. Bu nedenle, çevrenin korunması genellikle hükümet tarafından yürütülecek toplumsal eylem gerektirir (Smith, 1992: 23).

$\mathrm{Bu}$ çalışma, yirmi bir Avrupa Birliği (AB) ülkesinde 1995-2017 dönemi için hava kirliliği ile ilgili çeşitli kirlilik emisyonları ve çevre vergileri arasındaki ilişkiyi incelemeyi amaçlamaktadır. Çalışma $\mathrm{AB}$ ülkelerindeki çevre vergilerinin kirlilik emisyonlarını azaltmaktaki etkisini araştırmakta olup çevresel vergi sisteminin gelişiminin küresel emisyonu azaltma hedefine ulaşmada faydalı olacağını önermektedir.

Çevre vergilerinin çevre kirliliği üzerine etkilerini inceleyen çalışmalarda genellikle tek bir kirlilik göstergesi ele alınmıştır. $\mathrm{Bu}$ çalışmanın literatüre üç önemli katkısı vardır: Birincisi, $\mathrm{AB}$ ülkelerinde dört farklı çevresel kirlilik türü ile çevre vergileri ilişkisini panel veri analizinden yararlanarak ortaya koyan ilk çalışmadır. İkincisi, bu çalışma çevre vergilerinin çeșitli kirlilik emisyonlarını (seragazı, karbondioksit, sülfür oksit, nitrojen oksit) hangi yönde ve hangi oranda etkilediğini karşılaștırmalı olarak ortaya koymaktadır. Üçüncüsü ise, bu çalışmada $A B$ ülkelerinde çevre vergilerinin çevresel kirlilik emisyonlarını azaltmaya yardımcı olup olamayacağı araştırılmaktadır.

Çalıșma beş bölümden oluşmuştur. Giriş ile başlayan bölümü çalışmanın konusunu yansıtan literatür bölümü takip etmiştir. Üçüncü bölüm, ampirik model, veri ve yöntem ile ilgili açıklamalara ayrılmıştır. Dördüncü bölümde ampirik bulgular yorumlanmış ve sonuç ile çalışma tamamlanmıştır.

\section{LİTERATÜR}

Mevcut literatür yeşil kalkınmanın endüstriyel teknoloji, karbon yoğunluğu, makroekonomik belirsizlik ve çevresel düzenleme gibi birçok faktörden etkilendiğini ortaya koymaktadır. Bu kapsamda çevresel düzenleme araçlarından çevre vergisi ile ilgili analitik ve ampirik literatür çok geniş olmasına rağmen çevre vergisinin yeșil kalkınma üzerindeki etkisini dinamik ve çoklu etkileşimli bir bakış açısıyla çok fazla yansıtamamaktadır.

Bosquet (2000) çevre vergi reformunun öngörülen etkilerini incelemiştir. Bu amaçla elli altı farklı çalışmadan gelen yüz otuz dokuz simülasyondan elde edilen kanitları sentezlemiştir. Bulgular elli altı simülasyonun yani toplam simülasyonların yüzde 84'ü 
emisyonlarda azalma sağladığını, yetmiş beş simülasyonun yani toplam simülasyonların yüzde 73'ü istihdam yaratmaya yardımcı olacağını, altmış bir simülasyonun yani toplam simülasyonların yüzde 51'i GSYIHH kaybına neden olacağl, kırk dört simülasyonun yani toplam simülasyonların yüzde 77'si yatırımlarda azalmaya yol açacağını, elli altı simülasyonun yani toplam simülasyonların yüzde 94'ü tüketici fiyat endeksinde artışlara neden olacağını ortaya koymuştur.

Dökmen (2012) 1996-2010 dönemi verilerini kullanarak yirmi dokuz Avrupa ülkesi için çevre vergilendirmesinin ekonomik performans üzerindeki etkisini incelemiștir. Panel Vektör Otoregresif Model kullandığı çalışmasında elde ettiği bulgular çevre vergilerinde yaşanan bir şokun ekonomik büyüme üzerinde anlaml olarak pozitif tepkiler ortaya koyduğunu göstermiştir.

Morley (2012) 1995-2006 dönemi verilerini kullanarak 25 Avrupa Birliği üyesi ülke ve Norveç'ten oluşan bir panel için çevre vergilerinin etkinliğini incelemiștir. Bulgular çevre vergileri ve kirlilik arasında anlamlı bir negatif ilişkinin olduğunu, ancak çevre vergileri ile enerji tüketimi arasında hiçbir ilişki olmadığını ortaya koymuştur.

Miller ve Vela (2013) 1995-2010 dönemi için çoğu OECD üyesi olan ancak Çin ve Güney Afrika'nın yanı sıra Latin Amerika ve Doğu Avrupa'dan bazı ülkeleri de içeren elli ülke için çevre vergilerinin büyüklügünnün ülkelerin çevresel performansıyla ilgili olup olmadığ sorusuna yanıt aramışlardır. Kesit regresyonu ve panel dinamik regresyonu kullanan çalışmada bu tür vergilerden daha fazla geliri olan ülkelerin de $\mathrm{CO}_{2}$ emisyonunda, $\mathrm{PM}_{10}$ emisyonlarında ve fosil kaynaklarından enerji tüketiminde ve üretiminde daha yüksek düşüşler gösterdiği tespit edilmiştir.

Nanthakumar ve diğerleri (2014) Malezya için 1974-2010 dönemi zaman serisi verilerini kullanarak karbon vergilendirmesi ve ekonomik büyümenin çevre tehlikelerini nasıl etkilediğini araştırmışlardır. Sonuçlar karbon vergilendirme politikasının $\mathrm{CO}_{2}$ emisyonlarını kontrol etmek için etkisiz olduğunu göstermiştir.

Māris ve Jānis (2017) Bu yazıda yazarlar, Ekonomik İşbirliği ve Kalkınma Teşkilatı tarafından geliştirilen birleşik bir yaklaşım kullanarak Letonya'nın çevre politikasında kullanılan en önemli ekonomik araç olarak çevre vergilerinin değerlendirilmesine odaklanmışlardır. Araştırmanın amacı çevre vergilerinin etkinliğini değerlendirmek ve iyileştirme önerileri getirmektir. Çalışmanın sonuçları, mevcut çevre vergilerinin çevre kirliliği ve atık akışlarında önemli bir azalmaya yol açtığına dair çok az kanıt göstermiştir. Ekonomik büyüme gibi diğer faktörler, kaynak kullanımı ve kirliliğin itici güçleri olduğu; düşük vergi oranları, birçok muafiyet, geri ödeme ve oran indirimi gibi unsurların da Letonya'da bu vergilerin çevresel etkinliğini azalttığı tespit edilmiştir.

Niua ve diğerleri (2018) çevre vergi şokları ve karbon emisyonu arasındaki ilişkiyi tespit etmek amacıyla beş sektörden oluşan dinamik stokastik genel denge modeli geliştirmişlerdir. Analiz sonuçları Çin'de çevre vergisi şoklarının karbon emisyonlarının azaltılmasını sağlayabildiğini ortaya koymuştur.

Wand ve diğerleri (2018) çevre ve karbon vergilerinin getirilmesi yoluyla optimum güç karışımının belirlenmesi için deterministik bir optimizasyon modeli önermişlerdir. Bu iki verginin etkilerini göstermek için Çin'de Hebei Eyaleti'nin bir vaka çalışması sunulmuştur. Modelleme sonuçları, bu vergi politikalarının hava kalitesini de önemli ölçüde artırabileceğini göstermiştir. Daha yüksek vergi seviyelerinin yenilenebilir enerji üretiminin gelişimini teşvik edeceği ve farklı derecelerde $\mathrm{CO}_{2}$ ve hava kirletici emisyonunu azaltabileceği tespit edilmiştir.

Fan ve diğerleri (2019) dört boyutlu dinamik bir sistem kullanarak çevre vergisinin yeşil kalkınma üzerindeki etkisini analiz etmişlerdir. Farklı çevre vergi parametreleri altında ekonomik büyüme, kirlilik yoğunluğu ve kaynak yoğunluğunun gelişimine odaklanılmıştır. Çalışma çevre vergi 
uygulamasının yeşil kalkınmada aktif bir rol oynadığı görüşünü matematiksel olarak doğrulamıştır.

He ve diğerleri (2019) OECD ülkeleri ve Çin eyaletleri için çevre vergisinin kirleticileri azaltma üzerindeki etkisini incelemişlerdir. Otuz beș OECD ülkesine ait 1994-2016 dönemi verileri, otuz bir Çin eyaletine ait 2004-2016 dönemi verileri ile Panel ARDL modeli kullanılarak yapılan analizin bulguları çevre vergilerinin hem OECD ülkelerinde hem de Çin'de kirletici emisyonlarının azaltılmasına gerçekten yardımcı olduğunu göstermiştir. Gruplaşma regresyon sonuçlarından, OECD ülkeleri ve küçük ölçekli veya orta düzeyde çevre vergisi geliri ve daha yüksek ekonomik büyüme düzeyine sahip Çin iç eyaletleri daha iyi emisyon azaltma etkileri gösterirken, düşük endüstriyel katma değere sahip OECD ülkeleri ve yüksek endüstriyel katma değere sahip Çin iç eyaletleri çevre vergileri yoluyla kirletici emisyon azaltımı üzerinde daha anlamlı etkilere sahiptir.

Hu ve diğerleri (2019) çok bölmeli çok sektörlü hesaplanabilir genel denge modeli kullanarak Çin için 'kirlilik vergisi' politikasının hava kirletici emisyonları üzerindeki etkilerini ölçmüşlerdir. Sonuçlar mevcut vergi politikasının genel olarak birçok kısa ömürlü hava kirletici emisyonunu büyük ekonomik ölçeğe sahip bölgelerde ve yüksek emisyon yoğunluğuna sahip sektörlerde azaltabildiğini göstermiştir. Bununla birlikte, ulusal düzeyde, mevcut politikanın hava kirliliğini hafifletme üzerindeki genel etkisinin küçük olduğu sonucuna ulaşılmıştır.

Liu ve diğerleri (2019) çevre vergisinin bölge sakinlerinin mutluluğu üzerindeki etkisini incelemişlerdir. Bu amaçla 2015 Çin Genel Sosyal Araştırma Verileri ve Çin'deki 28 eyalet çevre vergisi oranları kullanılmıștır. Bulgular çevre kirliliğinin bölge sakinlerinin mutluluğu üzerinde olumsuz bir etkisi olduğunu ve çevre vergisi çıkarmanın hava ve su kirliliğinin bölge sakinlerinin mutluluğu üzerindeki olumsuz etkisini önemli ölçüde azalttığını göstermiştir.

\section{AMPİİK MODEL, VERİ SETI VE YÖNTEM}

$\mathrm{Bu}$ çalışmada 1995-2017 döneminde AB ekonomilerinde çevre vergisinin hava kirliliği ile ilgili çeşitli çevresel kirlilik türlerine etkisini incelemek için dört model önerilmiştir. Modellerdeki veriler OECD veri tabanından temin edilmiştir. $\mathrm{Bu}$ dört modelin analiz edilmesinde bağımlı değişken olarak seragazı emisyonu, $\mathrm{CO}_{2}$ emisyonu, nitrojenoksit emisyonu ve sülfiroksit emisyonu alınmıştır. Bununla birlikte, çalışmada çevre vergisi her bir denkleme açıklayıcı değişken olarak eklenmiştir. $\mathrm{Bu}$ bölümde öncelikle $\mathrm{AB}$ ülkelerindeki çevre vergisi ve çevresel kirlilik ile ilgili bilgilere yer verildikten sonra ekonometrik model ve veri seti açlklanacaktır. Daha sonra ampirik modelleri test ederken yararlanılan yöntemler ve ampirik sonuçlar ortaya konacaktır.

\subsection{AB Ülkelerinde Çevresel Kirlilik ve Çevre Vergisi}

Çalışmanın analiz kısmına geçmeden önce $\mathrm{AB}$ ülkelerinde çevresel kirlilik ve çevre vergisinin durumundan kısaca bahsedilecektir. Hava kirliliği, ekonomik faaliyetlerden kaynaklanan ve bireylerin sağlığını tehdit eden önemli bir sorundur. $A B$ ülkelerinde hava kirliliğine en fazla katkı sunan sülfür oksit $\left(\mathrm{SO}_{\mathrm{x}}\right)$, nitrojen oksit $\left(\mathrm{NO}_{x}\right), \mathrm{PM}, \mathrm{CO}_{2}, \mathrm{NH}_{3}, \mathrm{CH}_{4}$ gibi kirletici emisyonlarının 2010-2017 yılları arasında azaldığı görülmektedir. Örneğin, sülfür dioksit emisyonu 2000 yılından itibaren \%62 oranında, $\mathrm{NH}_{3}$ ise \%4 oranında azalmıştır. AB'de 2017 yılında toplam emisyonlar içerisinde en önemli hava kirleticilerinden biri olan nitrojen oksit emisyonundaki azalmada Avrupa emisyon standartlarının etkisi vardır (European Environment Agency, 2019: 193196).

$\mathrm{AB}$ enerji politikasının temel amaçlarından biri çevresel kirlilik, petrol fiyat oynaklığı, yabancı enerji kaynaklarına bağımlılık ve enerji güvenliğine çözümler sunan yenilenebilir enerjiyi teşvik etmektir. Yenilenebilir enerjiyi teşvik etmek amacıyla piyasa-tabanlı ve piyasatabanlı olmayan (tarifeler, yeşil sertifikalar, teşvikler, vergi uygulamaları vs.) farklı 


\section{düzenleyici tedbirler uygulanmıștır \\ (Balsalobre-Lorente ve diğerleri, 2018: 357). \\ politikası açısından önemli gelişmeleri özetlemek amacıyla oluşturulmuştur.}

$\mathrm{Bu}$ çerçevede aşağıda yer alan Tablo 1, AB çevre

\section{Tablo 1: AB Çevre Politikası Açısından Önemli Gelişmeler}

\begin{tabular}{|c|c|}
\hline $\begin{array}{l}\text { Birinci Çevre Eylem } \\
\text { Programı (1973-1976) }\end{array}$ & $\begin{array}{l}\text { Avrupa Topluluğu, Avrupa Konseyi'nin } 1972 \text { 'de bir Topluluk Çevre Politikası oluşturma taahhütlerine dayanarak } \\
\text { Kasım } 1973 \text { 'te bugünün "sürdürülebilir kalkınma" hakkındaki fikirlerinin birçok unsurunu içeren iddialı bu program } \\
\text { ile çevre politikalarına başlamıştır. Bu programda ekonomik kalkınma, refah ve çevrenin korunmasının karşılıklı } \\
\text { olarak birbirine bağımlı olduğu ve çevrenin korunmasının Topluluğun temel görevi olduğu" iddia edilmiştir. Çevresel } \\
\text { zararın önlenmesi, azaltılması ve kontrol altına alınması, ekolojik bir dengenin korunması ve doğal kaynakların } \\
\text { rasyonel kullanımı programın temel hedeflerindendir. }\end{array}$ \\
\hline $\begin{array}{c}\text { İkinci Çevre Eylem } \\
\text { Programı } \\
(1977-1981)\end{array}$ & $\begin{array}{l}\text { Bu program ele alınacak daha geniş bir sorun yelpazesi ile, yaklaşım ve hedef açısından ilkini takip etmiştir. Birinci ve } \\
\text { ikinci programlar (1973-1981) su ve hava için kalite değerlerini savunmuştur. Hava hedeflerine güçü politika } \\
\text { müdahalesi olmadan ulaşılabilirken, İçme suyu için kalite hedefleri çok katı idi. Sonraki eylem programlarında geçerli } \\
\text { olan on bir ilke ve çevre politikaları için öncelikler sıralanmıştır. }\end{array}$ \\
\hline $\begin{array}{l}\text { Üçüncü Çev } \\
\text { Programı }(19\end{array}$ & $\begin{array}{l}\text { Üçüncü program ve kısmen de olsa dördüncü program iç pazarın tamamlanması ile politika yaklaşımında önemli bir } \\
\text { değişikliği yansıtmaktadır. Ǔçüncü program, çevre politikalarının iç pazar için potansiyel risklerini ve faydalarını } \\
\text { vurgulamış ve iç pazar ile çevre politikaları arasındaki bağlantı, programlama ve faaliyetler için kilit bir itici güç haline } \\
\text { gelmiştir. }\end{array}$ \\
\hline 1987 & $\begin{array}{l}1987 \text { yıll, Avrupa Topluluğu çevre politikasında bir dönüm noktası olarak görülmektedir, çünkü çevresel koruma } \\
\text { kurucu antlaşmada kendi bölümünü almıştır. }\end{array}$ \\
\hline $\begin{array}{l}\text { Dördüncü Çevre Eylem } \\
\text { Programı (1987 - 1992) }\end{array}$ & $\begin{array}{l}\text { Program Birlik genelinde çevre standartlarının yüksek düzeyde uyumlaştırılmasını hedeflemiştir. Programda çevre } \\
\text { koruma tüm üretim sürecinde ilk defa entegre bir faaliyet olarak algllanmış, stratejik ekonomik sektörlerin çevre } \\
\text { üzerindeki etkisi analiz edilerek bir "sektörel yaklaşım" tartışmaya başlanmışve Illk kez, vergiler, sübvansiyonlar veya } \\
\text { ticarete konu olabilecek emisyon izinleri gibi yeni, teşvik tabanlı araçların değerlendirilmesi açıklanmıştır. }\end{array}$ \\
\hline 1992 & $\begin{array}{l}\text { Komisyon Haziran 1992'de UNCED konferansı yapılmadan önce, enerji/CO2 vergisi üzerine bir öneride bulunmuştur } \\
\text { fakat bazı ülkeler tarafından bu öneri reddedilmiştir. }\end{array}$ \\
\hline $\begin{array}{l}\text { Beşinci Çev } \\
\text { Programı }\left(1 C^{-1}\right.\end{array}$ & $\begin{array}{l}\text { Bu programın genel yaklaşımı ve stratejisi önceki programlardan farklı olmuştur. Program daha uzun vadeli hedefler } \\
\text { belirlemiş ve daha küresel bir yaklaşıma odaklanmıştır. Bu program ile AB düzeyinde politika hazırlı̆ı çok daha } \\
\text { katılımcı hale gelmiştir. Komisyon'un enerji/CO2 vergisi önerisi, iki yıllık müzakereler sırasında sulanmış ve nihayet } \\
1994 \text { 'te Topluluk vergisi olarak düşmüş̧ür. Mayıs } 1995 \text { 'te Komisyon, ara dönem için böyle bir vergi koyma } \\
\text { sorumluluğunu yeniden meşrulaştıran yeni bir teklif sundu. Ayrıca, bazı endüstrilerden, Avrupa Komisyonu'nun diğer } \\
\text { Genel Müdürlüklerinden ve Üye Devletlerden gelen güçlü muhalefet nedeniyle reform için başka inisiyatifler ve fikirler } \\
\text { de göz önünde bulundurulmuştur. }\end{array}$ \\
\hline $\begin{array}{l}\text { Altıncı Çevre Eylem } \\
\text { Programı }(2002-2012)\end{array}$ & $\begin{array}{l}\text { Program 2002-2012 dönemi için Avrupa Birliği'nde çevre politikası oluşturma çerçevesini belirler ve bu hedeflere } \\
\text { ulaşmak için alınması gereken önlemleri ana hatlarıyla belirtir. Program dört öncelikli alanı tanımlar: çevre ve sağllk, } \\
\text { doğa ve biyolojik çeşitlilik, iklim değişikliği ve doğal kaynaklar ve atıklar. Program, çevre koruma gerekliliklerinin tüm } \\
\text { Topluluk politikalarına ve eylemlerine tam entegrasyonunu teşvik eder ve Topluluğun sürdürülebilir kalkınma } \\
\text { stratejisinin çevresel bileşenini sağlar. 19-20 Mart } 2007 \text { tarihinde Brüksel'de AB } 1 \text {. Vergileme Forumu düzenlenmiş } \\
\text { ve vergi politikaları değerlendirilmiş, yeni dönem için çevre vergileri çerçevesinde, çevreyi kirletenler için daha } \\
\text { yüksek oranlı vergileme uygulamaları önerilmiştir. }\end{array}$ \\
\hline $\begin{array}{l}\text { Yedinci Çevre Eylem } \\
\text { Programı (2013-2020) }\end{array}$ & 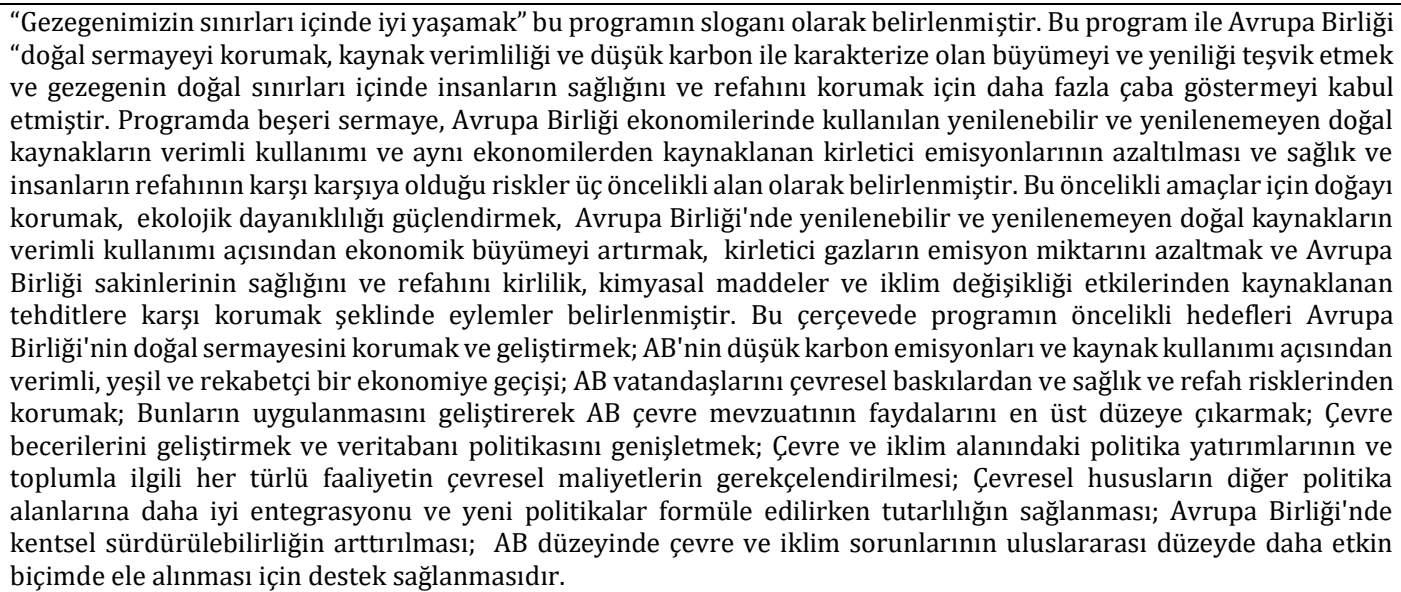 \\
\hline
\end{tabular}

Kaynak: Hey, 2007: 18-27; Halmaghi, 2016: 89-90; Özdemir, 2009. 


\section{ATAY POLAT - S. ERGÜN}

\subsection{Ampirik Model ve Veri Seti}

$\mathrm{Bu}$ çalışma $\mathrm{AB}$ ülkelerinde 1994-2017 döneminde çevre vergisinin seragazı emisyonu, $\mathrm{CO}_{2}$ emisyonu, sülfiroksit emisyonu ve nitrojenoksit emisyonuna etkisini incelemektedir. $\quad \mathrm{Bu}$ amacin gerçekleştirilebilmesi için kurulan hipotezler şu şekildedir:

Hipotez 1: $A B$ ülkelerinde çevre vergilerinin sera gazı emisyonu üzerine azaltıcı bir etkisi vardır.

Hipotez 2: $\mathrm{AB}$ ülkelerinde çevre vergilerinin karbondioksit $\left(\mathrm{CO}_{2}\right)$ emisyonu üzerine azaltıcı bir etkisi vardır.

Hipotez 3: AB ülkelerinde çevre vergilerinin nitrojenoksit emisyonu üzerine azaltıcı bir etkisi vardır.
Hipotez 4: $A B$ ülkelerinde çevre vergilerinin sülfiroksit emisyonu üzerine azaltıcı bir etkisi vardır.

Analizde kullanacağımız verilerin belirlenmesinde $\mathrm{He}$ ve diğerleri (2019) çalışmasından yararlanılmıştır. Bazı ülkelerde 1995-2017 dönemine ait veriler bulunmadığından dolayı analize $21 \mathrm{AB}$ ülkesi dahil edilmiştir. Bu ülkeler; Avusturya, Belçika, Çek Cumhuriyeti, Danimarka, Estonya, Finlandiya, Fransa, Almanya, Yunanistan, Macaristan, İrlanda, İtalya, Lüksemburg, Hollanda, Polonya, Portekiz, Slovakya, Slovenya, İspanya, İsveç, İngiltere'dir. Analizde kullandığımız bağımlı değişkenler toplam sera gazı emisyonu (ton), toplam $\mathrm{CO}_{2}$ emisyonu (ton), toplam sülfür oksit emisyonu (ton) ve toplam nitrojen oksit emisyonu (ton) iken, bağımsız değişken ise $\mathrm{AB}$ ülkelerinin kişi başına düşen çevre vergisi (dolar)'dir. Verilerin tamamı OECD veri tabanından temin edilmiștir.
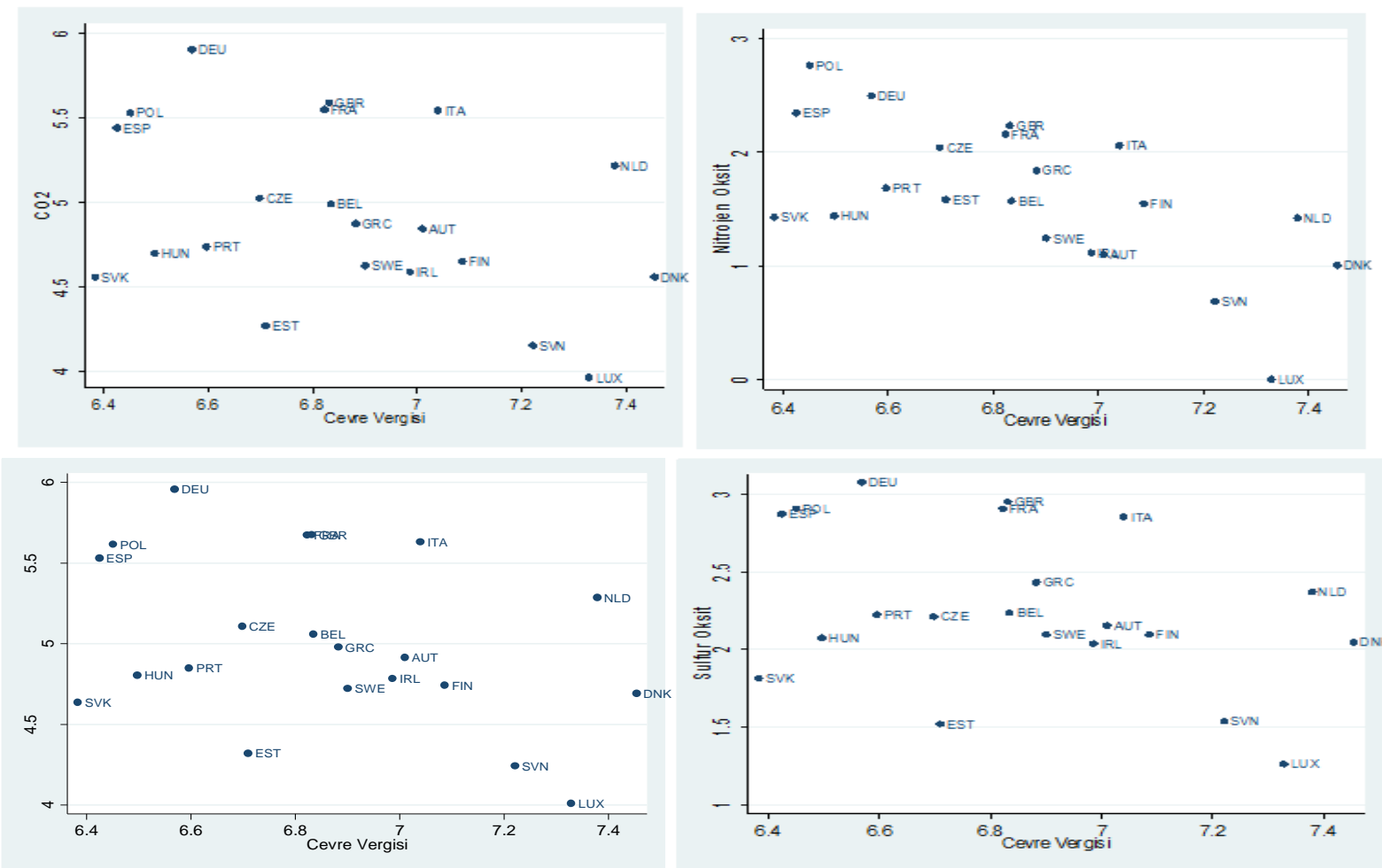

Şekil 2. Çevre Vergisi ve Çevresel Kirlilik Arasındaki İlişki

Castiglione ve diğerleri (2014) yaptığı çalışmasında $\mathrm{AB}$ ülkelerini ekonomik, çevresel ve kurumsal performans açısından üç gruba ayırmıştır. Birinci grup (G1), sanayi ve hizmet sektörleriyle (Avusturya, Belçika, Danimarka,
Fransa, Finlandiya, Hollanda, İsveç ve İngiltere) gelişen piyasa ekonomisi ülkeleri; ikinci grup (G2) ulusal veya bölgesel düzeyde gelişme gösteren piyasa ekonomisi ülkeleri (Yunanistan, İrlanda, İtalya ve Portekiz); 
üçüncü grup (G3) ise eski geçiş ekonomileridir (Bulgaristan, Çek Cumhuriyeti, Estonya, Macaristan, Polonya, Slovakya, Slovenya). Şekil 2, çevre vergisi ve çevresel kirlilik arasındaki ilişkiyi göstermek amacıyla hazırlanmıştır. Şekil 2'ye göre daha yüksek gelir düzeyine sahip olan G1 ülkelerinin, G2 ve G3 ülke gruplarına göre daha yüksek çevre vergisine karşılık daha düşük çevresel kirliliğe (İspanya dışında) sahip oldukları gözlemlenmiştir. $\mathrm{Bu}$ durum, ekonomik kalkınmanın ileri evresindeki ülkelerin çevresel koruma politikalarını arttırdıklarını teyit etmektedir.

Kişi başına çevre vergisinin toplam seragazı emisyonu (seragazı), toplam $\mathrm{CO}_{2}$ emisyonu $\left(\mathrm{CO}_{2}\right)$, toplam nitrojenoksit emisyonu (nitrojenoksit), toplam sülfiroksit emisyonu (sülfiroksit) gibi çevresel kirlilik göstergeleri üzerine etkisini araştırmak amacıyla (1), (2), (3) ve (4) numaralı ampirik modeller kullanılmıştır:

Kirlilik Modeli 1: Seragazı = f(çevre vergisi) (1)

Kirlilik Modeli 2: $\mathrm{CO}_{2}=\mathrm{f}($ çevre vergisi)

Kirlilik Modeli 3: Nitrojenoksit= f(çevre vergisi) (3)

Kirlilik Modeli 4: Sülfiroksit= f(çevre vergisi) (4)

Tüm modellerdeki değişkenlerin logaritmik dönüşümleri yapılarak analiz tahminleri yapılmıștır. Böylece, veriler arasındaki keskin farklılığın azaltılması neticesinde değișkenler daha iyi bir dağılım özelliği göstermektedirler. Doğal logaritmik dönüşüm verideki otokorelasyon ve değișen varyans sorunlarının da ortadan kaldırılmasına yardımcı olmaktadır. Ayrıca, logaritmik dönüşümlü modellerden elde edilen sonuçlar daha tutarlı ve etkin olmaktadır (Zafar ve diğerleri 2020: 4). Ampirik modellerin logaritmik dönüşümlü versiyonu aşağıdaki denklemlerde yer almaktadır:

Kirlilik Modeli 1: $\ln$ Seragazlit $_{1}=\alpha_{i t}+\beta_{1} \ln$ çevre vergisi $i_{i t}+\varepsilon_{i t}$

Kirlilik Modeli 2: $\ln \mathrm{CO}_{2 \mathrm{it}}=\theta_{\text {it }}+\phi_{1} \ln$ çevre vergisiit $+v_{\text {it }}$
Kirlilik Modeli 3: ln Nitrojenoksitit $=\beta_{1} \ln$ çevre vergisi $i_{i t}+\pi_{i t}$

Kirlilik Modeli 4: $\ln$ Sülfüroksit ${ }_{i t}=\ln \delta_{i t}+p_{1} \ln$ çevre vergisiit $+\lambda_{\text {it }}$

Burada, i birimleri $(1, \ldots . ., 21)$, t zaman serisini $(1995, \ldots . ., 2017), \beta_{1}, \phi_{1}, \beta_{1}$ ve $p_{1}$ çevre vergisinin her bir model için esneklik katsayısını ve $\varepsilon i t$, vit, $\pi$ it ve $\lambda$ it hata terimlerini ifade etmektedir.

\subsection{Yöntem İle İlgili Teorik Çerçeve}

$\mathrm{Bu}$ çalışmada çevre vergisi ve çevresel kirlilik ilişkisini belirlemek amaciyla kurulan modellerin test edilmesinde yatay kesit bağımlılık ve homojenlik testlerini takiben ikinci nesil birim kök testi kullanılmış, değişkenlerin eşbütünleşme ilişkisi ve uzun dönem katsayı tahminlerinin ardından nedensellik testi sonuçlarına yer verilerek analizler tamamlanmıştır.

\subsubsection{Yatay Kesit Bağımlılık (CD) Testi ve Homojenlik Testi}

Panel veri analizlerine başlamadan önce yatay kesit bağımlılığının (CD) incelenmesi tutarlı sonuçların elde edilebilmesi için önemlidir. CD problemi gözlenemeyen unsurlardan kaynaklanmakta ve panel veride sıkça rastlanan şoklardan oluşmakta; benzer şekilde ekonomilerin ekonomik ve finansal bütünleşmesi de bu soruna yol açabilmektedir. Örneğin, şoklara ev sahipliği yapan ülkenin planlaması ve politika önerileri diğer ülkeleri etkileyebilir. Bu yüzden, geleneksel birim kök testlerini kullanarak değişkenlerin durağanlığının belirlenmesi sahte regresyona yol açabilir. Bu sorundan kaçınmak için yatay kesit bağımlılığı testi yapmak gerekmektedir (Khan ve diğerleri 2020: 5). Serilerde yatay kesit bağımlılığının varlığının incelenmesi amacıyla Pesaran (2004)'ın geliştirdiği CD testi ve Breusch ve Pagan (1980)'ın geliştirildiği LM testleri kullanılmaktadır. Așağıdaki denklem CD testine ait açıklamaları içermektedir:

$C D=\sqrt{\frac{2 T}{N(N-1)}}\left(\sum_{i=0}^{N-1} \sum_{j=i+1}^{N} \rho_{i j}\right)$ 
Denklemdeki $\mathrm{N}$ birim sayısını, $\mathrm{T}$ ise zamanı göstermektedir.

Panel veride yatay kesit bağımlılığını incelemek için aşağıdaki denklemde yer alan LM testinden faydalanılmaktadır.

$y_{i t}=\propto_{i t}+\beta_{i} x_{i t}+\varepsilon_{i t}$

Burada i birimi ve $t$ zamanı gösterir. Bu iki test için sıfır hipotezinde yatay kesit bağımlılığının bulunmadığı varsayılır iken; alternatif hipotez panel veride yatay kesit bağımlılığının bulunduğunu açıklamaktadır.

Panel veri analizlerinde serilerin homojen veya heterojenliğinin tespit edilmesi, sonrasında uygulanacak eşbütünleşme ve nedensellik testlerine karar vermede önem arzetmektedir. $\mathrm{Bu}$ çalışmada Pesaran ve Yamagata (2008)'ın geliştirdiği Delta testinden yararlanılarak homojenlik durumu incelenmiştir.

\subsubsection{Yatay Kesit Birim Kök Testi}

Yatay kesit bağımlılığı olduğu zaman birinci nesil birim kök testlerinin etkin olmadığ söylenir. Çünkü, bu testler yatay kesit bağımlılığının olmadığı varsayımına dayanmaktadır. Bu çalışmada seride yatay kesit bağımlılığı olması durumunda tutarlı sonuçlar veren Pesaran (2007) tarafından geliștirilen Pesaran CIPS testi kullanılmıștır. $\mathrm{Bu}$ test panelde yatay kesit bağımlılığı ve heterojenlik durumunda kullanılmaktadır. Literatürde pek çok çalışmada değişkenlerin durağanlık durumlarını incelemek amacıyla ikinci nesil birim kök testlerinden yararlanılmıştır. Yatay kesit bağımlılığı aşağıdaki denklemle açılklanabilir:

$\Delta x_{i t}=\gamma_{i t}+\delta_{i} x_{i t-1}+\vartheta_{i} T+\sum_{j=0}^{n} \theta_{i t} \Delta x_{i, t-j}+$ $\varepsilon_{i t}$

Burada, $x_{i t}$ ilgili değişkeni, i yatay kesiti, $\mathrm{t}$ zamanı, $\varepsilon_{i t}$ modelin kalıntılarını ifade etmektedir. $\mathrm{Bu}$ test alternatif hipotezin durağanlık sınamasına karşılık sıfır hipotezin durağan olmadığını dikkate almaktadır.

\subsubsection{Westerlund Eşbütünleşme Testi}

Bu çalışmada model değişkenleri arasında uzun dönem ilişkisinin bulunup bulunmadığını göstermek için eşbütünleşme testinden yararlanılmıştır. Birim kök testi sonuçlarını takiben birinci nesil eşbütünleşme yönteminin kullanımı yanlı sonuçlar ortaya çlkarabilmektedir. Çünkü, bu testler model değişkenleri arasında uzun dönem eşbütünleşme ilişkisini belirlemesine rağmen yatay kesit bağımlılığını dikkate almamaktadır (Zafar ve diğerleri, 2020: 5). Bundan dolayı bu çalışmada değişkenler arasında uzun dönem ilişkisini incelemek amacıyla Durbin-Hausman prensibine dayanan Westerlund (2008) eşbütünleşme testi kullanılmıștır. Westerlund eşbütünleşme testi $\mathrm{DH}$-panel $\left(\mathrm{DH}_{\mathrm{p}}\right)$ ve $\mathrm{DH}$-grup $\left(\mathrm{DH}_{\mathrm{g}}\right)$ șeklinde iki istatistik önermektedir ve $\mathrm{DH}$ prensibi yatay kesiti dikkate almak için ortak faktörü kullanır. Bu testin diğer avantajı durağan tahmincilerin varlığına karşı dirençli olmasıdır (Westerlund, 2008).

$\mathrm{Bu}$ testte sıfır hipotezi eşbütünleşmenin olmadığı şeklinde kurulmaktadır. DurbinHausman (DH) testlerini elde etmek için EKK tahmincileri ve araç değişkenlerden yararlanılmaktadır. $\mathrm{DH}_{\mathrm{g}}$ (grup ortalama) ve $\mathrm{DH}_{\mathrm{p}}$ (panel) testlerini elde etmek amaciyla aşağıdaki denklemler kullanılabilmektedir:

$D H_{g}=\sum_{i=1}^{N} s_{i}^{\wedge}\left(\varphi_{1 i}-\varphi_{2 i}\right) \sum_{t=2}^{T} \widehat{e_{l}^{2}}(t-1)$

$D H_{p}=\widehat{S_{n}}\left(\varphi_{1 i}-\varphi_{2 i}\right)^{2} \sum_{i=1}^{N} \sum_{t=2}^{T} \hat{e}_{i}^{2}(t-1)$

$\varphi_{1}, \varphi_{i}{ }^{\prime}$ in EKK tahmincisini ve $\varphi_{2}$, havuzlanmış EKK tahmincisini göstermektedir. Panel testin her bir i için alternatif hipotezine $\mathrm{H}_{1}=\varphi_{i}=\varphi$ ve $\varphi<1$ karşıllk bütün $\mathrm{i}=1$..... N için sıfır hipotezi $\mathrm{H}_{0}=\varphi_{i}=1$ şeklinde kurulmaktadır. Alternatif ve sifır hipotezleri altında ortak otoregresif parametre varsayılmaktadır. Diğer taraftan, $\mathrm{DH}_{\mathrm{g}}$ testi için sıfır hipotezi en az bazı i'ler için eşbütünleşme yoktur şeklinde kurulmaktadır ve $\mathrm{H}_{1}=\varphi_{\mathrm{i}}<1$ ile gösterilen alternatif hipoteze karşı sınanmaktadır. Sıfır hipotezi reddedilirse bazı panel birimlerde uzun dönem ilişki vardır.

3.3.4. Uzun Dönem Esneklik Katsayılarının Tahmini

$\mathrm{Bu}$ çalışmada modellerdeki uzun dönem esneklik katsayılarının tahmin edilmesinde Bond ve Eberhardt (2013) ve Eberhardt ve 
Bond (2009)'un ileri sürdüğü Augmented Mean Group (AMG) tahmincisi kullanılmıştır. Seride yatay kesit bağımlılığının, heterojenliğin ve birim kök sorununun bulunması durumunda birinci nesil tahmincilerin kullanımı başarısız sonuçların elde edilmesine sebep olmaktadır. Fakat AMG tahmincisi yatay kesit bağımlılığının varlığında etkindir ve heterojen panel veride çok iyi sonuçlar sağlamaktadır (Khan ve diğerleri, 2020: 6). Bu yüzden, bu sorunların mevcut olduğu serilerimiz için AMG tahmincisinden faydalanılarak uzun dönem esneklik katsayı tahminleri yapılmıştır.

\subsubsection{Dumitrescu Hurlin Nedensellik Testi}

Dumitrescu ve Hurlin (2012) nedensellik testinde paneli olușturan ülkeler/bölgeler vb. birimler arasındaki yatay kesit bağımsızlığı ve heterojenliği dikkate alınmakta iken diğer taraftan $\mathrm{T}>\mathrm{N}$ ve $\mathrm{N}>\mathrm{T}$ durumlarında da uygulanabilmektedir.
Ayrıca, değişkenlerin durağan olması gerekmekte ve dengesiz panellerde de etkili sonuçlar elde edilebilmektedir (Dumitrescu ve Hurlin, 2012).

$\mathrm{Bu}$ testte sifır hipotezi bütün birimlerde nedenselliğin olmadığını ( $\mathrm{H}_{0}: \beta_{\mathrm{i}}=0, \forall_{i}=1, \ldots, N$ ) buna karşıllk alternatif hipotez de bazı birimlerde nedenselliğin olduğunu $\left(\mathrm{H}_{1}: \beta_{\mathrm{i}}=0\right.$, $\forall_{i}=1, \ldots ., \mathrm{N}_{1}$ ve $\left.\beta_{\mathrm{i}} \neq 0, \quad \forall_{i}=N_{1}+1, \quad \mathrm{~N}_{1}+2, \ldots, \mathrm{N}\right)$ ifade etmektedir. Durbin Hausman testinde hesaplana test istatistiklerinin $\mathrm{p}<.01, \mathrm{p}<.05$ ve $\mathrm{p}<.10$ gibi anlamlılık düzeylerinden küçük olması durumunda sifir hipotezinin red edilmesine karar verilmekte ve bu durumda bazı birimlerde nedenselliğin olduğu ortaya çlkmaktadır (Gül ve İnal, 2017: 76).

Özetleyecek olursak, bu çalışmada Şekil 3'de gösterilen Khan ve diğerleri (2020)'nin çalışmasındaki ekonometrik yöntem sıralaması takip edilmiştir.

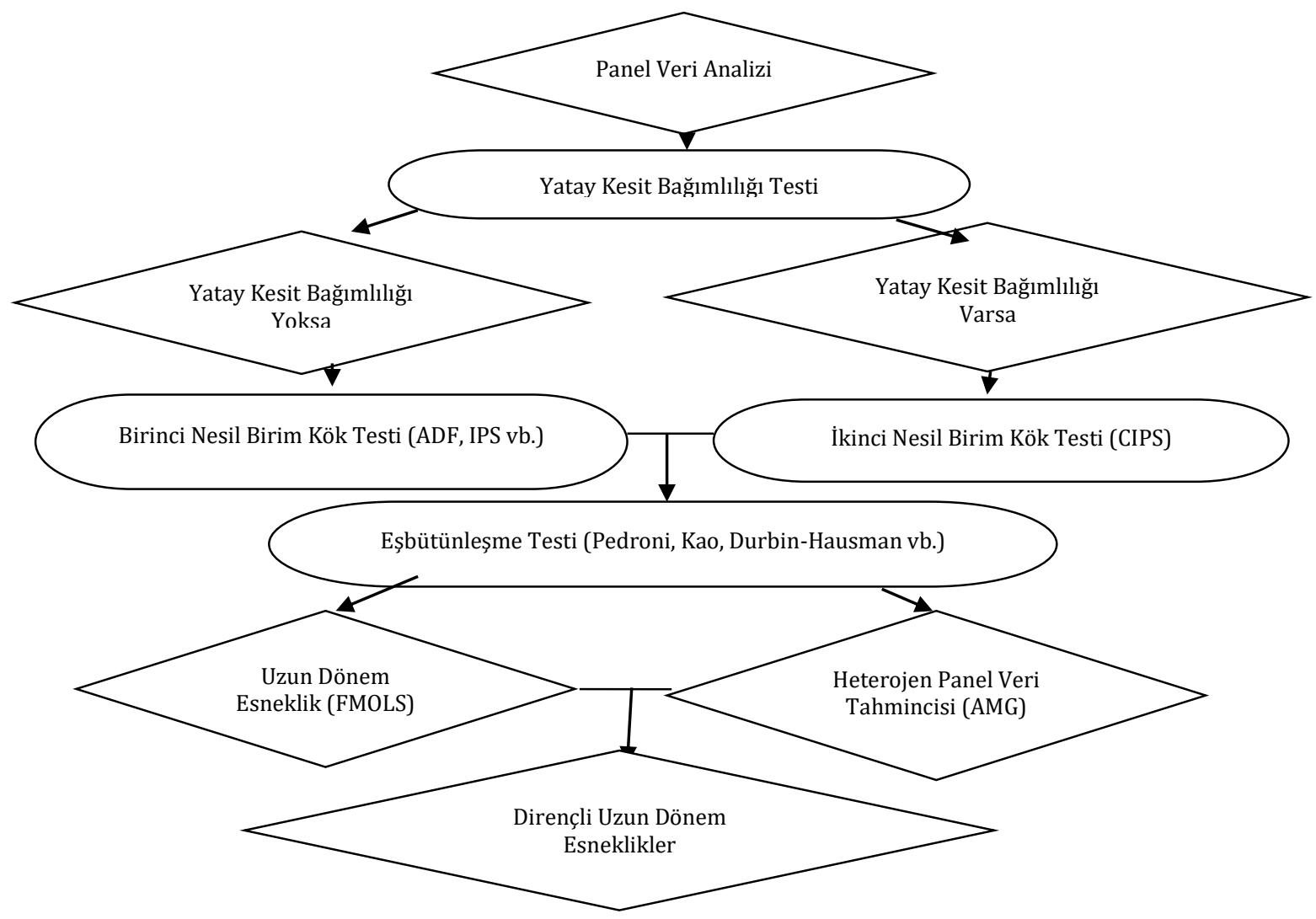

Şekil 3. Ekonometrik Yöntemin Sistematiğine Bakış (Kaynak: Khan ve diğerleri, 2020: 7. ) 


\section{AMPIRIK SONUÇLAR}

$\mathrm{Bu}$ bölümde ampirik analizlerden elde edilen sonuçlara yer verilmiştir.

\subsection{Tanımlayıcı İstatistikler}

İlk olarak, seçilmiş değişkenlerin tahmin edilen tanımlayıcı istatistiklerine ait bilgiler Tablo 2'de sunulmuştur.
Tablo 2'ye göre en yüksek ortalama kirlilik değerine seragazı (5.062 ton) emisyonu sahip iken en düşük değer sülfiroksit (2.033 ton) emisyonuna aittir. Ayrıca, çevre vergisinin ortalama değeri ise 6.733 dolardır.

Tablo 2. Tanımlayıcı İstatistiklerin Özeti

Bağımsız Değişken: Çevre Vergisi

\begin{tabular}{ccccccc}
\hline Ülkeler & İstatistikler & $\operatorname{lnSeragazl}$ & $\operatorname{lnCO}_{2}$ & $\operatorname{lnNitrojenoksit}$ & lnSülfiroksit & InÇevre Vergisi \\
\hline \multirow{4}{*}{$A B$} & Ortalama & 5.062 & 4.973 & 2.438 & 2.033 & 6.733 \\
& Maksimum & 6.057 & 5.982 & 3.424 & 3.389 & 7.830 \\
& Minimum & 3.936 & 3.886 & 1.263 & -0.004 & 4.667 \\
& Standart Hata & 0.521 & 0.528 & 0.504 & 0.694 & 0.465 \\
& Gözlem Sayısı & 483 & 483 & 483 & 483 & 483 \\
\hline
\end{tabular}

\subsection{Yatay Kesit Bağımlılık Testi ve Homojenlik Testi Sonuçları}

Ampirik tahminler modelde yatay kesit bağımlılı̆̆ının varlığını kontrol etmekle başlamaktadır. Tablo 3 yatay kesit bağımlılık sonuçlarını vermiştir. Bütün testlerde sıfır hipotezinin reddedilmesi durumunda yatay kesit bağımlılığının varlığı doğrulanmaktadır.
Yatay kesit bağımlılı̆̆ı testine ilave olarak veriler heterojen ise eğimin homojenlik varsayımı altında tahmin yapmak yanlış olacaktır. Bu yüzden, bu sorunu kontrol etmek amacıyla çalışmada Pesaran ve Yamagata (2008)'nın geliștirdiği homojenlik testinden yararlanılmıştır. Tablo 3'de her bir model için sıfır hipotezinin eğimde homojenlik varsayımı \%1 anlamlılık düzeyinde reddedilmiştir.

Tablo 3. Yatay Kesit Bağımlılık ve Homojenlik Testleri Sonuçları

\begin{tabular}{|c|c|c|c|c|}
\hline Değişkenler & LM & $\overline{C D_{\perp M}}$ & $\mathrm{CD}$ & $\mathrm{LM}_{\mathrm{adj}}$ \\
\hline lnSeragazl & $334.303^{*}$ & $6.065^{*}$ & $-1.395 * * *$ & $156.946^{*}$ \\
\hline $\ln \mathrm{CO}_{2}$ & $311.900^{*}$ & $4.972 *$ & $-1.314 * * *$ & $156.504^{*}$ \\
\hline InNitrojenoksit & $292.459 *$ & $4.024 *$ & $-1.910 * *$ & $156.088^{*}$ \\
\hline lnSülfüroksit & $293.940^{*}$ & $4.096^{*}$ & $-1.594 * * *$ & $137.569^{*}$ \\
\hline InÇevrevergisi & $311.194 *$ & $4.938^{*}$ & $-2.469^{*}$ & $136.209^{*}$ \\
\hline Homojenlik & Kirlilik Modeli 1 & Kirlilik Modeli 2 & Kirlilik Modeli 3 & Kirlilik Modeli 4 \\
\hline Delta & $16.669^{*}$ & $14.886^{*}$ & $18.904 *$ & $17.554 *$ \\
\hline Delta $_{a d j}$ & $17.820^{*}$ & $15.892 *$ & $20.210^{*}$ & $18.776^{*}$ \\
\hline
\end{tabular}

Not: ${ }^{*} \mathrm{p}<.01,{ }^{* *} \mathrm{p}<.05,{ }^{* * *} \mathrm{p}<.10$ düzeyinde anlamlılı̆̆ ifade etmektedir.

\subsection{Panel CIPS Birim Kök Testi Sonuçları}

Yatay kesit bağımlılığının varlığı durumunda değişkenlerin eşbütünleşik özelliklerini araştırmak için ikinci nesil birim kök testleri kullanılmalıdır. Dolayısıyla, CIPS birim kök testi ile durağanlık sınanmış ve test sonuçlarına Tablo 4'te yer verilmiştir. CIPS testi sonuçları model değişkenlerinin düzeyde birim kökün 
olduğunu fakat birinci farkta durağanlığı ifade etmektedir.

Tablo 4. CIPS Birim Kök Testi Sonuçları

\begin{tabular}{ccc}
\hline & \multicolumn{2}{c}{ CIPS } \\
\hline Değişkenler & Düzey & Birinci Fark \\
\hline InSeragazı & -1.98 & $-3.31^{*}$ \\
InCO 2 & -2.05 & $-3.42^{*}$ \\
InNitrojenoksit & -2.33 & $-3.14^{*}$ \\
InSülfüroksit & -2.26 & $-2.63^{* *}$ \\
InÇevrevergisi & -1.67 & $-2.85^{*}$
\end{tabular}

Not: Test istatistikleri sabitli model için hazırlanmıştır. ${ }^{*} \mathrm{p}<.01,{ }^{* *} \mathrm{p}<.05, * * * \mathrm{p}<.10$ anlamlılık düzeyinde seriler durağandır. CIPS için \%1, \%5 ve \%10 kritik değerlerinin sırayla $-2.81,-2.66$ ve -2.58 olduğu görülmektedir.

\subsection{Westerlund Eşbütünleşme Testi Sonuçları}

Bütün değişkenlerin birinci farkında durağan oldukları belirlendikten sonra değişkenler arasındaki eşbütünleşme ilişkisi değerlendirilebilmektedir.

Bu çalışmada Westerlund (2008) eşbütünleşme testi kullanılmış ve bu testin sonuçlarına Tablo 5 'te yer verilmiştir. Sonuçlar panel veride eşbütünleşme yoktur şeklindeki sıfır hipotezinin reddedilmesine işaret etmektedir. Yani, 1995-2017 döneminde AB bölgesinde model değişkenleri arasında eşbütünleşmenin varlığl ispatlanmıştır. Dolayısıyla, değişkenlerin uzun dönem hareketlerini analiz etmek faydalı olacaktır (Khan ve diğerleri, 2020: 6).

Tablo 5. Westerlund Eșbütünleșme Testi Sonuçları

\begin{tabular}{|c|c|c|c|c|}
\hline & Kirlilik Modeli 1 & Kirlilik Modeli 2 & Kirlilik Modeli 3 & Kirlilik Modeli 4 \\
\hline & T-istatistiği & T-istatistiği & T-istatistiği & T-istatistiği \\
\hline DH-panel & $3.549^{*}$ & $2.979^{*}$ & $5.955^{*}$ & $7.600^{*}$ \\
\hline DH-grup & $2.863^{*}$ & $12.956^{*}$ & $11.557^{*}$ & $2.819^{*}$ \\
\hline
\end{tabular}

Sonraki aşamada, çevre vergisinin çevresel kirlilikler üzerine etkilerinin yönü ve büyüklüğünü belirlemek amacıyla uzun dönem esneklikler AMG testi ile tahmin edilecektir. Kirlilik modelleri için analiz sonuçları Tablo 6'da sunulmuştur.

\subsection{Uzun Dönem Katsayı Tahminleri Sonuçları}

Tablo 6'da Kirlilik Modeli 1 için elde edilen uzun dönem esneklik katsayılarına ait sonuçlarla ilgili bilgiler şöyledir:

i. Çevre vergileri seragazı emisyonunu Avusturya, Fransa, Lüksemburg, İspanya, İrlanda, Portekiz ülkelerinde pozitif yönde ve anlamlı bir şekilde etkilemektedir. Finlandiya, Estonya ve Slovenya'da seragazı emisyonu pozitif fakat anlamsızdır. ii. Cevre vergilerinin seragazı emisyonunu artırıcı etkisinin en fazla olduğu ülke Lüksemburg (\%0.368) iken en az olduğu ülke Avusturya (\%0.11)'dır.

iii. Çevre vergileri seragazı emisyonunu Belçika, Danimarka, Almanya, Hollanda, İsveç, İngiltere, Yunanistan, İtalya, Çek Cumhuriyeti, Macaristan, Polonya ve Slovakya ülkelerinde negatif yönde ve anlamlı bir șekilde etkilemektedir. Dolayısıyla çevre vergilerinin çevresel kirlilik üzerine negatif etkisinin olduğu ülke sayısı pozitif etkisinin olduğu ülke sayısından daha fazladır.

iv. Çevre vergileri seragazı emisyonunu en fazla \%0.298 ile Çek Cumhuriyetinde en az \%0.033 ile Polonya'da azaltmaktadır.

v. Son olarak panelin genelinde çevre vergilerinin seragazı emisyonunu 


\section{ATAY POLAT - S. ERGÜN}

negatif etkilediği ancak esneklik katsayısının anlamsız olduğu ortaya çlkmıştır.

Kirlilik Modeli 2 için elde edilen sonuçlar şöyledir:

i. Çevre vergileri Avusturya, Lüksemburg, İspanya, İrlanda, Portekiz ve Slovenya'da $\mathrm{CO}_{2}$ emisyonunu artırıcı bir etkiye sahiptir. Fransa, Finlandiya ve Estonya'da pozitif yönde fakat anlamsız bir ilişki tespit edilmiştir.

ii. Çevre vergileri en fazla Lüksemburg $(\% 0.428)$, en az Avusturya $(\% 0.145)^{\prime}$ daki çevresel kirliliği artırmaktadır. vi. Çevre vergileri Belçika, Danimarka, Almanya, İsveç, İngiltere, Yunanistan, Çek Cumhuriyeti, Macaristan, Polonya ve Slovakya ülkelerinde $\mathrm{CO}_{2}$ emisyonunu azaltmakta ve katsayllar anlamlıdır. Ayrıca Hollanda ve İtalya'da negatif etki varken katsayı anlamsızdır. Çevre vergilerinin $\mathrm{CO}_{2}$ emisyonuna negatif etkisinin olduğu ülke sayısının pozitif etkisinin olduğu ülke sayısından daha fazla olduğu görülmektedir.

iii. Çevre vergileri en fazla Danimarka (\%0.301)'yı en az Polonya (\%0.04)'daki kirliliği azaltmaktadır.

iv. Panelin genelinde ise çevre vergilerinin çevresel kirlilik üzerine pozitif ancak anlamsız bir etkisi vardır.

Tablo 6. Kirlilik Modelleri İçin Doğrusal Uzun Dönem Esneklik Katsayıları Sonuçları

\begin{tabular}{|c|c|c|c|c|c|c|c|c|}
\hline \multicolumn{9}{|c|}{ Bağımsız Değișken: Çevre Vergisi } \\
\hline \multirow[b]{2}{*}{ Ülkeler } & \multicolumn{2}{|c|}{ Kirlilik Modeli 1} & \multicolumn{2}{|c|}{ Kirlilik Modeli 2} & \multicolumn{2}{|c|}{ Kirlilik Modeli 3} & \multicolumn{2}{|c|}{ Kirlilik Modeli 4} \\
\hline & Katsayı & $\begin{array}{l}\text { Olasılık } \\
\text { Değeri }\end{array}$ & Katsayı & $\begin{array}{l}\text { Olasılık } \\
\text { Değeri }\end{array}$ & Katsayı & $\begin{array}{l}\text { Olasılık } \\
\text { Değeri }\end{array}$ & Katsayı & $\begin{array}{l}\text { Olasılık } \\
\text { Değeri }\end{array}$ \\
\hline Avusturya & $0.110^{*}$ & 0.000 & $0.145^{*}$ & 0.000 & $0.269^{*}$ & 0.000 & 0.047 & 0.505 \\
\hline Belçika & $-0.169 * *$ & 0.020 & $-0.132^{* * *}$ & 0.070 & 0.032 & 0.400 & $0.575^{* *}$ & 0.021 \\
\hline Cek Cum. & $-0.298^{* *}$ & 0.041 & $-0.045^{*}$ & 0.002 & $0.064^{* * *}$ & 0.084 & 0.038 & 0.919 \\
\hline Danimarka & $-0.216^{*}$ & 0.001 & $-0.301^{*}$ & 0.001 & $-0.139 *$ & 0.001 & $-0.784^{*}$ & 0.000 \\
\hline Estonya & 0.005 & 0.767 & 0.005 & 0.768 & -0.002 & 0.921 & $0.127^{* * *}$ & 0.082 \\
\hline Finlandiya & 0.036 & 0.416 & 0.019 & 0.716 & 0.002 & 0.967 & 0.172 & 0.191 \\
\hline Fransa & 0.245 & 0.659 & 0.064 & 0.301 & $0.180^{* * *}$ & 0.052 & $-0.412^{* *}$ & 0.033 \\
\hline Almanya & $-0.163^{*}$ & 0.000 & $-0.135^{*}$ & 0.000 & $-0.199 *$ & 0.000 & $-0.777^{*}$ & 0.000 \\
\hline Yunanistan & $-0.219^{*}$ & 0.001 & $-0.174^{* *}$ & 0.038 & $-0.471^{*}$ & 0.000 & $-1.352^{*}$ & 0.000 \\
\hline Macaristan & $-0.044^{* *}$ & 0.041 & $-0.078^{*}$ & 0.001 & 0.289 & 0.154 & $-1.289^{*}$ & 0.000 \\
\hline Írlanda & $0.119^{*}$ & 0.001 & $0.222^{*}$ & 0.000 & $0.198^{*}$ & 0.001 & $0.408^{* *}$ & 0.012 \\
\hline Italya & $-0.064^{* * *}$ & 0.096 & -0.004 & 0.913 & $0.297^{*}$ & 0.000 & -0.010 & 0.905 \\
\hline Lüksemburg & $0.368^{*}$ & 0.000 & $0.428^{*}$ & 0.000 & $0.581^{*}$ & 0.000 & $-0.232^{* * *}$ & 0.054 \\
\hline Hollanda & $-0.148^{*}$ & 0.000 & -0.009 & 0.616 & $-0.147^{*}$ & 0.000 & 0.069 & 0.564 \\
\hline Polonya & $-0.033^{* *}$ & 0.017 & $-0.040^{*}$ & 0.005 & $-0.081^{* *}$ & 0.037 & -0.048 & 0.374 \\
\hline Portekiz & $0.154^{* * *}$ & 0.055 & $0.193^{* *}$ & 0.022 & $0.192^{*}$ & 0.001 & $0.686^{*}$ & 0.000 \\
\hline Slovakya & $-0.043^{*}$ & 0.000 & $-0.063^{*}$ & 0.000 & -0.005 & 0.782 & 0.054 & 0.748 \\
\hline Slovenya & 0.397 & 0.331 & $0.072^{* * *}$ & 0.074 & 0.039 & 0.567 & 0.167 & 0.461 \\
\hline İspanya & $0.337^{*}$ & 0.000 & $0.363^{*}$ & 0.000 & $0.276^{*}$ & 0.000 & $1.299^{*}$ & 0.000 \\
\hline İsveç & $-0.217^{*}$ & 0.000 & $-0.279^{*}$ & 0.000 & $-0.262^{*}$ & 0.000 & -0.026 & 0.786 \\
\hline Ingiltere & $-0.203^{* *}$ & 0.011 & $-0.124^{* * *}$ & 0.069 & $-0.186^{* * *}$ & 0.054 & -0.117 & 0.654 \\
\hline PANEL & -0.017 & 0.646 & 0.006 & 0.882 & 0.032 & 0.532 & -0.067 & 0.620 \\
\hline
\end{tabular}

Kirlilik Modeli 3 için tespit edilen sonuçlar şöyledir:

i. Çevre vergileri Avusturya, Fransa, Lüksemburg, İspanya, İrlanda, İtalya, Portekiz ve Çek Cumhuriyeti ülkelerinde nitrojenoksit emisyonunu artırıcı bir etkiye sahiptir. Ayrıca Belçika, Finlandiya, Macaristan ve Slovenya'da pozitif yönde fakat anlamsız bir ilișki tespit edilmiştir.

ii. Çevre vergileri en fazla Lüksemburg $(\% 0.581)$, en az Çek Cumhuriyeti $(\% 0.054)$ 'daki çevresel kirliliği artırmaktadır.

iii. Çevre vergileri Danimarka, Almanya, Hollanda, İsveç, İngiltere, Yunanistan, ve Polonya ülkelerinde nitrojenoksit 
emisyonunu azaltmakta ve katsayılar anlamlıdır. Ayrıca Estonya ve Slovakya'da negatif etki varken katsayı anlamsizdır.

iv. Çevre vergileri en fazla Yunanistan $(\% 0.471)$ 'yı en az Polonya (\%0.081)'daki kirliliği azaltmaktadır.

v. Panelin genelinde ise çevre vergilerinin çevresel kirlilik üzerine pozitif ancak anlamsız bir etkisi vardır.

Kirlilik modeli 4 için analiz sonuçları şöyledir:

i. Çevre vergileri Belçika, İspanya, İrlanda, Portekiz ve Estonya ülkelerinde sülfüroksit emisyonunu artırıcı bir etkiye sahiptir. Ayrıca Avusturya, Finlandiya, Hollanda, CCek Cumhuriyeti, Slovakya ve Slovenya'da pozitif yönde fakat anlamsız bir ilişki tespit edilmiştir.

ii. Çevre vergileri en fazla İspanya (\%1.299), en az Estonya (\%0.127)'daki çevresel kirliliği artırmaktadır.

iii. Çevre vergileri Danimarka, Fransa, Almanya, Lüksemburg, Yunanistan, ve Macaristan ülkelerinde sülfüroksit emisyonunu azaltmakta ve katsayılar anlamlıdır. Ayrıca İsveç, İngiltere, İtalya, Polonya'da negatif etki varken katsayı anlamsızdır.

iv. Çevre vergileri en fazla Yunanistan (\%1.352)'yı en az Lüksemburg (\%0.232)'daki kirliliği azaltmaktadır.

v. Panelin genelinde ise çevre vergilerinin çevresel kirlilik üzerine negatif ancak anlamsız bir etkisi vardır.

AMG tahmincisi sonuçları çevre vergilerinin pek çok $A B$ ülkesinde en fazla seragazı üzerine negatif etkisinin olduğunu göstermiştir. Seragazı emisyonunu, sirasiyla $\mathrm{CO}_{2}$, nitrojenoksit ve sülfüroksit emisyonları takip etmiştir.

\subsection{Nedensellik Testi Sonuçları}

Son olarak, nedensellik testi sonuçları tartışılmıștır. Çünkü, model değişkenleri arasındaki nedensellik ilişkisinin belirlenmesi politika önerileri yapabilmek için önemli sonuçlar ortaya koymaktadır. Bu çalışmada Dumitrescu ve Hurlin (2012)'in geliştirdiği heterojen nedensellik testi uygulanmış ve test sonuçlarına Tablo 7'de yer verilmiştir.

Tablo 7. Dumitrescu-Hurlin Nedensellik Testi Sonuçları

\begin{tabular}{|c|c|c|c|}
\hline Nedenselliğin Yönü & Test & Test İstatistiği & Olasılık Değeri \\
\hline \multirow{2}{*}{$\Delta \operatorname{lnSeragazı} \neq>\Delta$ Çevrevergisi } & Z-bar & 1.607 & 0.109 \\
\hline & Z-bar tilde & 1.001 & 0.242 \\
\hline \multirow{2}{*}{$\Delta$ Çevrevergisi $\neq>\Delta \ln$ Seragazı } & Z-bar & $8.914^{*}$ & 0.000 \\
\hline & Z-bar tilde & $6.969 *$ & 0.000 \\
\hline \multirow{2}{*}{$\Delta \operatorname{lnCO}_{2} \neq>\Delta$ Çevrevergisi } & Z-bar & $5.304^{*}$ & 0.000 \\
\hline & Z-bar tilde & $2.084^{* *}$ & 0.045 \\
\hline \multirow{2}{*}{$\Delta$ Çevrevergisi $\neq>\Delta \operatorname{lnCO}_{2}$} & Z-bar & $4.633^{*}$ & 0.000 \\
\hline & Z-bar tilde & $1.704^{* * *}$ & 0.093 \\
\hline \multirow{2}{*}{$\Delta \ln$ Nitrojenoksit $\neq>\Delta$ Çevrevergisi } & Z-bar & $4.781^{*}$ & 0.000 \\
\hline & Z-bar tilde & $3.127 *$ & 0.003 \\
\hline \multirow{2}{*}{$\Delta$ Çevrevergisi $\neq>\Delta \ln$ Nitrojenoksit } & Z-bar & $2.228^{* *}$ & 0.033 \\
\hline & Z-bar tilde & 1.193 & 0.196 \\
\hline \multirow{2}{*}{$\Delta \operatorname{lnSülfüroksit~} \neq>\Delta$ Çevrevergisi } & Z-bar & $4.298^{*}$ & 0.000 \\
\hline & Z-bar tilde & $3.199 *$ & 0.002 \\
\hline \multirow{2}{*}{$\Delta$ Çevrevergisi $\neq>\Delta \ln$ Sülfüroksit } & Z-bar & 0.779 & 0.295 \\
\hline & Z-bar tilde & 0.325 & 0.378 \\
\hline
\end{tabular}

$\operatorname{Not}^{*} \mathrm{p}<.01,{ }^{* *} \mathrm{p}<.05,{ }^{* * *} \mathrm{p}<.10$ anlamlılık düzeyinde değişkenler arasında nedenselliğin varlığını ortaya koymaktadır. Nedenselliğin yönü ise $\neq>$ simgesi gösterilmiştir.

Nedensellik testi sonuçları aşağıdaki gibi özetlenmiştir:

i. Çevre vergisinden seragazı emisyonuna doğru tek yönlü nedensellik ilişkisi mevcut olmasına rağmen, seragazı emisyonundan çevre vergisine doğru nedensellik ilişskisi bulunamamıştır. 


\section{ATAY POLAT - S. ERGÜN}

ii. Cevre vergisi ile $\mathrm{CO}_{2}$ emisyonu arasında iki yönlü nedensellik ilișkisi bulunmuştur.

iii. Çevre vergisi ile nitrojen oksit emisyonu arasında iki yönlü nedensellik ilişkisi bulunmuștur.

iv. Son olarak, sülfüroksit emisyonundan çevre vergisine tek yönlü nedensellik ilişkisi vardır. Ancak, çevre vergisinden sülfüroksit emisyonuna doğru nedensellik ilișkisi bulunamamıștır.

Şekil 4'te panel nedensellik testi sonuçları topluca sunulmuştur.

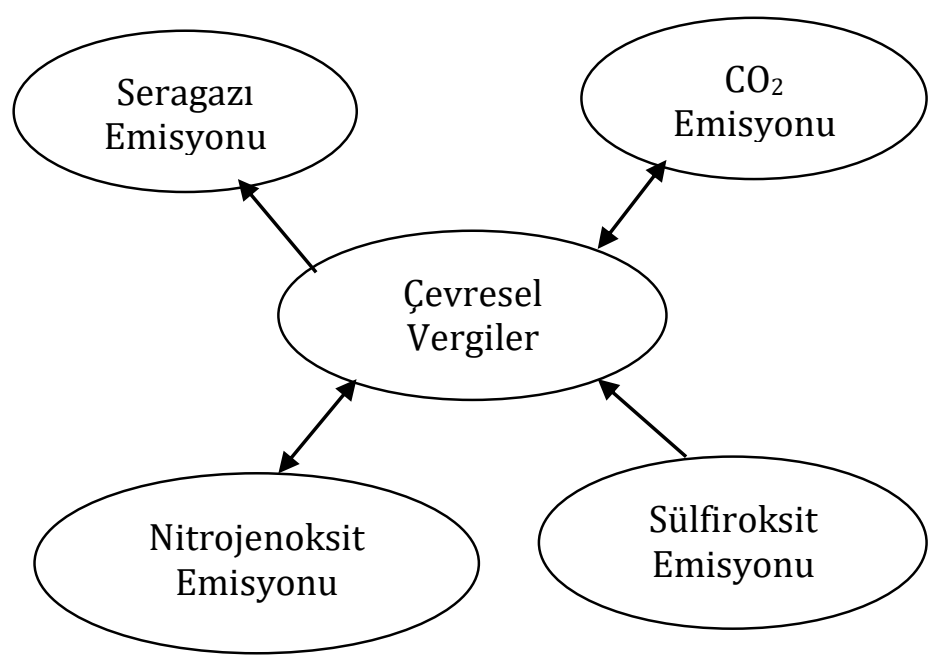

Şekil 4. AB Ülkelerinde Çevresel Kirlilik Göstergeleri ve Çevre Vergileri Arasındaki Nedensellik İlişkisi

\section{SONUÇ}

Ekonomik büyümenin neden olduğu çevresel sorunlar hükümetler üzerinde olumsuz çevresel etkileri azaltmanın yollarını bulma baskısını artırmaktadır. Hükümetlerin kullanımına sunulan çeşitli çevresel politika araçları (yönetmelikler, bilgi programları, yenilik politikaları, çevresel sübvansiyonlar ve çevre vergileri gibi) mevcuttur. Bu kapsamda özellikle çevre vergileri bu araç setinin önemli bir parçasını oluşturur. Çevre vergilerini diğer politika araçlarından ayıran çeşitli avantajları mevcuttur; örneğin: çevresel etkinlik, ekonomik verimlilik, kamu gelirini arttırma yeteneği ve şeffaflık gibi. Çevre vergilerinin tasarımı ve bunların uygulanmasında politik ekonomi ile ilgili hususlar, genel ekonomik etkilerinin önemli belirleyicisidir.

Vergiler, çevre maliyetlerini "fiyatlandırarak" doğrudan piyasa başarısızlığını giderir. Çünkü vergiler, piyasaların çevresel etkileri göz ardı etmesine neden olan piyasa başarısızlığını doğrudan ele almaktadır. İyi tasarlanmış bir çevre vergisi, bir mal veya faaliyetin fiyatını, başkalarına uyguladığı çevresel zararın maliyetini yansıtacak şekilde arttırır. Bașkalarına verilen zararın maliyeti - "dıșsallık" - böylece piyasa fiyatlarına içselleștirilir. $\mathrm{Bu}$, tüketicilerin ve firmaların kararlarında bu maliyetleri dikkate almasını sağlar. Böylece vergiler, tüketicilere ve işletmelere çevresel zararı azaltmanın en düşük maliyetli yolunu belirleme esnekliği sağlar.

Bu çalışmada, 1995-2017 döneminde 21 AB ülkesi için çevre vergisinin çeșitli hava kirleticilerini azaltıcı etkisi araştırılmıştır. Bu amacın gerçekleştirilmesinde kurulan dört modelde bağımlı değișken olarak seragazı emisyonu, $\mathrm{CO}_{2}$ emisyonu, nitrojenoksit emisyonu ve sülfiroksit emisyonu alınmış iken, açıklayıcı değişken çevre vergisidir. Çalışmada çevre vergisi ve çevresel kirlilik ilişkisini belirlemek amaciyla kurulan modellerin test edilmesinde yatay kesit bağımlılık ve homojenlik testlerini takiben CIPS ikinci nesil birim kök testi kullanılmış, değişkenlerin 
eşbütünleşme ilişkisi Westerlund testi ile incelenmiş ve AMG tathmincisi ile uzun dönem katsayı tahminlerinin ardından DumitrescuHurlin nedensellik testi sonuçlarına yer verilerek analizler tamamlanmıștır.

Serilerde yatay kesit bağımlılığının ve heterojenliğinin bulunmasından hareketle, CIPS testi sonuçları değişkenlerin birinci farkında durağan olduklarını kanıtlamıștır. Ardından, her bir model için yapilan eşbütünleşme test sonuçları değişkenler arasındaki uzun dönemli ilişkinin varlığını tespit etmiştir. Panel AMG tahmincisi sonuçları, çevre vergilerinin pek çok $A B$ ülkesinde uzun dönemde kirlilik emisyonlarının azaltılmasında anlamlı bir etkiye sahip olduğunu ortaya koymuştur. Çevre vergileri seragazı emisyonunu Belçika, Danimarka, Almanya, Hollanda, İsveç, İngiltere, Yunanistan, İtalya, Çek Cumhuriyeti, Macaristan, Polonya ve Slovakya ülkelerinde negatif yönde; $\mathrm{CO}_{2}$ emisyonunu Belçika, Danimarka, Almanya, İsveç, İngiltere, Yunanistan, Çek Cumhuriyeti, Macaristan, Polonya ve Slovakya ülkelerinde negatif yönde; nitrojenoksit emisyonunu Danimarka, Almanya, Hollanda, İsveç, İngiltere,
Yunanistan ve Polonya ülkelerinde negatif yönde; sülfüroksit emisyonunu Danimarka, Fransa, Almanya, Lüksemburg, Yunanistan ve Macaristan ülkelerinde negatif yönde etkilemiştir. Çevre vergilerinin çevresel kirliliği azaltıcı etkisinin olduğunu bulduğumuz benzer sonuçlara literatürde Morley (2012), Miller ve Vela (2013), Niua ve diğerleri (2018), Wand ve diğerleri (2018), He ve diğerleri (2019) ve $\mathrm{Hu}$ ve diğerleri (2019) çalışmalarında rastlanmıștır. Son olarak nedensellik testi sonuçları çevre vergisinden seragazı emisyonuna doğru tek yönlü, çevre vergisi ile $\mathrm{CO}_{2}$ emisyonu ve nitrojenoksit emisyonları arasında çift yönlü, sülfüroksit emisyonundan çevre vergisine doğru tek yönlü nedensellik ilişkisini ortaya koymuştur.

Sonuç olarak, AB ülkelerinde çevre vergileri sanayileşme sürecinde kirliliğin azaltılması amacıyla etkili bir araç olarak kullanılabilir. Kirlilik emisyonlarının azaltılması ise yeterli ekonomik kaynağa bağlıdır. Dolayısıyla, politika yapıcılarının ekonomik kalkınma sürecinde çevre vergileri uygulamaları çevreyi koruyabilmek adına fon akışını da sağlayabilir.

\section{KAYNAKÇA}

Alvarez, M. (2019). Distributional effects of environmental taxation: an approximation with a meta-regression analysis. Economic Analysis and Policy, 62, 382-401.

Balsalobre-Lorente, D., Shahbaz, M. Roubaud, D., Farhani ve S. (2018). How economic growth, renewable electricity and natural resources contribute to $\mathrm{CO} 2$ emissions?. Energy Policy, 113, 356-367.

Breusch, T.S. ve Pagan, A.R. (1980). The lagrange multiplier test and its applications to model specification in econometrics. The Review of Economic Studies, 47(1), 239-253.

Bond, S.R. ve Eberhardt, M. (2013). Accounting for unobserved heterogeneity in panel time series models. University of Oxford.
Bosquet, B. (2000). Environmental tax reform: does it work? a survey of the empirical evidence. Ecological Economics, 34, 19-32.

Cadoret, I., Galli, E. ve Padovano, F. (2020). Environmental taxation: Pigouvian or Leviathan?. Journal of Industrial and Business Economics.

Castiglione, C., Infante, D. Minervini, M. T. ve Smirnova, J. (2014). Environmental taxation in Europe: what does it depend on?. Cogent Economics \& Finance, 2(1), 967362, DOI: 10.1080/23322039.2014.967362.

Congressional Budget Office (2013). Effects of a carbon tax on the economy and the environment. CBO reports 44223. 
Donatella B. ve Mario M. (2010). Pigouvian Tax, Abatement Policies and Uncertainty on the Environment. Journal of Economics, 1-2.

Dökmen, G. (2012). Environmental tax and economic growth: a panel VAR analysis. Erciyes Üniversitesi İktisadi ve İdari Bilimler Fakültesi Dergisi, 40, Haziran-Aralık, 43-65.

Dumitrescu, E.I. ve Hurlin, C. (2012). Testing for granger non-causality in heterogeneous panels. Economic Modelling, 29(4), 14501460.

Eberhardt, M. ve Bond, S. (2009). Cross-section dependence in nonstationary panel models: a novel estimator. MPRA Paper No. 17692, University Library of Munich, Germany.

Fan, X., Li, X. ve Yin, J. (2019). Impact of environmental tax on green development: a nonlinear dynamical system analysis. PLoS ONE, 14(9): e0221264.

Gül, E. ve İnal, V. (2017). Hava kirliliği ve ekonomik büyüme ilişkisi: zamanla değișen panel nedensellik analizi. Sakarya İktisat Dergisi, 6(2), 70-82.

Halmaghi, E. E. (2016). Environmental action programmes of the European Union programmes supporting the sustainable development strategy of the European Union. De Gruyter Open Scientific Bulletin, XXI, 2(42), 87-90

He, P., Ning, J., Yu, Z., Xiong, H., Shen, H. ve Jin, H. (2019). Can environmental tax policy really help to reduce pollutant emissions? an empirical study of a panel ARDL model based on OECD countries and China. Sustainability, 11(16), 4384.

Hey, C. (2007). EU environmental policies: a short history of the policy strategies. EU Environmental Policy Handbook.

Hu, X., Sun, Y., Liu, J., Meng, J., Wang, X., Yang, H. ...Tao, S. (2019). The impact of environmental protection tax on sectoral and spatial distribution of air pollution emissions in China. Environmental Research Letter, 14, 054013.
European Environment Agency (2019). The European Environment-State and Outlook 2020.

Intosal Workıng Group On Environmental Auditıng (2016). Market Based Instruments for Environmental Protection and Management. Jakarta, Indonesia.

Khan, A., Muhammad, F., Chenggang, Y., Hussani, J., Bano, S. ve Khan, M. A. (2020). The impression of technological innovations and natural resources in energy-growthenvironment nexus: a new look into BRICS economies. Science of the Total Environment, 1-11.

Kosonen, K. (2012). Regressivity of Environmental Taxation: Myth or Reality? European Commission Working Paper N.32.

Liu, Y., ,Li, R. L., Song, Y. ve Zhang, Z. J. (2019). The role of environmental tax in alleviating the impact of environmental pollution on residents' happiness in China. International Journal of Environmental Research and Public Health, 16, 4574.

Māris, J. ve Jānis, B. (2017). Assessment of the environmental tax system in Latvia. The NISPAcee Journal of Public Administration and Policy, X(2), Winter 2017/2018.

Miller, S. J. ve Vela, M. A. (2013). Are Environmentally Related Taxes Effective?. Inter-American Development Bank, IDB-WP467.

Morley, B. (2012). Empirical Evidence on the Effectiveness of Environmental Taxes. Applied Economics Letters, 19(18), 1817-1820.

Nanthakumar, L., Shahbaz, M. ve Taha, R. (2014). The effect of green taxation and economic growth on environment hazards: the case of Malaysia. MPRA Paper No. 56843.

Niua, T., Yaoa, X., Shaob, S., Lic, D. ve Wangda, W. (2018). Environmental tax shocks and carbon emissions: an estimated college structural change and economic dynamics DSGE model. Structural Change and Economic Dynamics, 47, 9-17. 
OECD (2011). Environmental Taxation A Guide for Policy Makers, September.

OECD (2017). Environmental Fiscal Reform Progress, Prospects and Pitfalls.

Özdemir, B. (2009). Küresel kirlenme sürdürülebilir ekonomik büyüme ve çevre vergileri. Maliye Dergisi, 156, Ocak-Haziran, 136.

Pesaran, M.H. (2004). General diagnostic tests for cross section dependence in panels. IZA, Bonn, Germany. Discussion Paper No. 1240.

Pesaran, M.H. (2007). A simple panel unit root test in the presence of cross-section dependence. Journal of Applied Econometrics, 22(2), 265-312.

Pesaran, M. H. ve Yamagata, T. (2008). Testing slope homogenity in large panels. Journal of Econometrics, 142(1), 50-93.

Rosiek, J. (2015). The impact of environmental tax policy on sustainable development of the EU economies. DEA Approach 11th International Conference of ASECU September 10-11, Cracow, Poland.

Smith, S. (1992). Taxation and the environment: a survey. Fiscal Studies, 13 (4), 21-57.

Wang, B., Liu, L., Huang, G.H., Li, W. ve Xie, Y.L. (2018). Effects of carbon and environmental tax on power mix planning - a case study of $i$

Westerlund, J. (2008). Panel cointegration tests of the fisher effect. Journal of Applied Econometrics, 23, 193-233.

Zafar, M.W., Shahbaz, M., Sinha, A., Sengupta, T. ve Qin, Q. (2020). How renewable energy consumption contribute to environmental quality? the role of education in OECD countries. Journal of Cleaner Production, 268, 1-12. 